\title{
En orden a sus virtudes y facultades medicinales: um estudo sobre o Paraguay Natural Ilustrado de José Sánchez Labrador S. J.
}

Regarding its virtues and medicine faculties: a study about Paraguay Natural Ilustrado written by José Sánchez Labrador

Eliane Cristina Deckmann Fleck, Mariana Alliatti Joaquim and Maico Biehl

\section{CpenEdition}

\section{Journals}

Electronic version

URL: http://journals.openedition.org/corpusarchivos/1709

DOI: 10.4000/corpusarchivos.1709

ISSN: 1853-8037

Publisher

Diego Escolar

\section{Electronic reference}

Eliane Cristina Deckmann Fleck, Mariana Alliatti Joaquim y Maico Biehl, «En orden a sus virtudes y facultades medicinales: um estudo sobre o Paraguay Natural Ilustrado de José Sánchez Labrador S. J. », Corpus [En línea], Vol 6, No 2 | 2016, Publicado el 22 diciembre 2016, consultado el 19 abril 2019 URL : http://journals.openedition.org/corpusarchivos/1709; DOI : 10.4000/corpusarchivos.1709

This text was automatically generated on 19 April 2019 


\section{En orden a sus virtudes y facultades medicinales: um estudo sobre o Paraguay Natural Ilustrado de José Sánchez Labrador S. J.}

Regarding its virtues and medicine faculties: a study about Paraguay Natural Ilustrado written by José Sánchez Labrador

Eliane Cristina Deckmann Fleck, Mariana Alliatti Joaquim and Maico Biehl

\section{EDITOR'S NOTE}

Fecha de recepción del original:

Fecha de aceptación para publicación:

\section{Uma breve introdução}

1 Dentre os principais efeitos da difusão de imagens negativas do colonialismo ibérico pela historiografia dos séculos XVIII e XIX, está a percepção de que a censura inquisitorial, o catolicismo e os jesuítas obstruíram "o pensamento científico nos países e regiões de colonização ibérica". Esta posição acabou por reforçar a existência de uma dicotomia entre prática científica e cultura católica, e minimizar o importante papel desempenhado pela sensibilidade científica barroca própria do período - que conjuga a intervenção divina com o experimentalismo - para a "formulação de modelos explicativos com validade universal". ${ }^{1}$ 
2 As reflexões em torno das múltiplas atividades exercidas pelos membros da Companhia de Jesus - tanto como religiosos à frente de aldeamentos, reduções e colégios, quanto como administradores de fazendas encarregadas da manutenção dos colégios jesuíticos sempre dividiram as opiniões dos historiadores. E, por mais de quatro séculos, recaiu sobre a Ordem uma apreciação negativa - tributária, em grande medida, da eficiente difusão de uma historiografia anti-jesuítica.

$3 \mathrm{Na}$ atualidade, historiadores como Luís Miguel Carolino afirmam que a ciência “recentemente designada de 'ciência jesuíta' ou 'filosofia natural jesuíta"' deve ser vista "como uma corrente multifacetada, marcadamente heterogênea, com fortes tensões internas e em diálogo constante com o debate filosófico e científico seu contemporâneo". ${ }^{2}$ Outros, como Beatriz Domingues, defendem que os jesuítas assimilaram "algumas ideias caras à Ilustração - ainda que [de forma] seletiva e católica", razão pela qual se deve relativizar a "abordagem tradicional que atribuiu à Companhia de Jesus uma visão retrógrada e resistente a mudanças, associada à tradição medieval católica e barroca". ${ }^{3}$ Também para os historiadores Domingo Ledezma e Luís Millones Figueroa, ${ }^{4}$ os jesuítas incorporaram e assimilaram paulatinamente as ideias e os métodos de estudo da Ilustração, contudo, o conhecimento que produziram, com base na observação e na experiência - tão caras aos integrantes da Ordem -, não reduziu o fascínio exercido pelos mistérios da natureza. Para os jesuítas,

el estúdio no era un mero apéndice de la vida espiritual sino también una forma de participar en los debates intelectuales de la época y el modo de desarrollar un proyecto científico propio. (...) Estudiar la naturaleza americana contribuyó a los diferentes aspectos de su misión. ${ }^{5}$

4 Para Ugo Baldini, professor da Universidade de Pádua, a Companhia de Jesus produziu uma grande síntese intelectual e doutrinal de "praticamente toda a Escolástica, antiga e recente, filtrada através de certas exigências do humanismo, da maior disponibilidade de textos clássicos e da aplicação a eles de métodos filológicos". Assim, todas as realizações intelectuais dos membros da Companhia, por mais variadas que tenham sido, reportam-se a “(...) premissas conceituais, tradições epistemológicas [e] remetem a uma estrutura de pensamento substancialmente compacta e reconhecível". ${ }^{6}$

5 Já para o historiador e filósofo da ciência argentino Miguel de Asúa, os jesuítas conseguiram realizar uma harmoniosa síntese entre ciência e religião, dedicando-se à astronomia, à cartografia, à botânica médica, à física experimental e à história natural e produzindo "uma ciência basicamente barroca com relações tardias com a ciência ilustrada do século XVIII, que esteve a serviço do projeto religioso da Companhia de Jesus".7 Os jesuítas ocuparam, segundo Asúa, "o cenário cultural e científico do Rio da Prata (...) antes da expulsão da Companhia em 1767", ${ }^{8}$ e desenvolveram, especialmente, nas reduções jesuíticas, uma "interessante atividade científica", como atestam "as histórias naturais do Novo Mundo e os manuscritos de matéria médica", evidências de que a Companhia de Jesus era "a frente mais avançada da ciência no Rio da Prata". ${ }^{9}$ A riqueza e a variedade de atividades científicas desenvolvidas nas missões jesuíticas instaladas no território do Rio da Prata e em uma região do Paraguay histórico refutam, ainda, a falsa ideia "de que el Río de la Plata colonial fue un yermo en cuanto a cultura científica se refiere". ${ }^{10}$ Este mesmo autor, em seu livro Science in the Vanished Arcadia. Knowledge of Nature in the Jesuit Missions of Paraguay and Río de la Plata (2014), ressalta que, se por um lado, a ciência jesuíta pode ser caracterizada como uma expressão da cultura barroca que teve seu auge durante o período moderno - e, portanto, identificada, 
com os objetivos missionários de Companhia de Jesus -, por outro lado, a ciência jesuíta no Rio da Prata colonial se configurou como uma articulação de formas europeias de pensamento com sentidos e categorias nativas. ${ }^{11}$

6 A historiadora mexicana Ivone Del Valle, por sua vez, tem ressaltado o papel que os jesuítas desempenharam na criação de redes de conhecimento e na formação de uma epistemologia muito particular no século XVIII, e, em especial, a importância dos colégios da Companhia de Jesus para a circulação de ideias e para a realização de experimentalismos, das quais resultou tanto a validação, quanto a contestação de práticas e saberes consagrados na Europa. ${ }^{12}$ Este aspecto é também destacado por Ledezma e Millones Figueroa, para quem durante o século XVII e o XVIII, o projeto científico da Companhia de Jesus se constituía, efetivamente, em uma alternativa clara e influente no mapa cultural europeu, na medida em que "as mais reconhecidas figuras da intelligentsia jesuíta na Europa refletiram sobre a natureza do Novo Mundo", a partir das informações que recebiam "dos irmãos e padres jesuítas que atuavam nas áreas coloniais periféricas", que, além de integrarem um grupo "qualificado e confiável (...) ao redor do mundo", constituíam uma notável rede de "agentes viajantes da Companhia" e de "uma vasta rede de informação dentro da própria ordem". ${ }^{13}$

7 Já o historiador equatoriano Jorge Cañizares Esguerra propõe que tomemos estes personagens como "pensadores", que, apesar de habitarem regiões marginais no cenário intelectual do período - áreas consideradas apenas e tradicionalmente como receptoras de conhecimentos produzidos em outras partes do mundo -, foram decisivos na construção de determinados conhecimentos. Neste processo, muito teriam contribuído as bibliotecas e as boticas instaladas nos colégios, reduções e fazendas da Companhia de Jesus, que não apenas evidenciariam a penetração e a apropriação de ideias, como também o diálogo que os membros da ordem mantinham com a ciência e a filosofia modernas,$^{14} \mathrm{em}$ sintonia com "o gosto e o respeito pelo trabalho intelectual (...), segundo um 'modo de proceder' (...) que marcou suas atuações e no qual se inscreveu um 'dever de inteligência". ${ }^{15}$

8 Em artigo de 2005, Antonella Romano já chamava nossa atenção para duas questões que avaliamos como fundamentais e que consideramos na investigação em curso. A primeira está relacionada com a pouca importância dada ao mundo iberoamericano para a história das ciências, como se a atividade científica da Ordem [nos espaços extra-europeus] tivesse se concentrado exclusivamente no Oriente; e a segunda diz respeito ao quão fundamental é inscrever as atividades da Companhia no mundo americano dentro de uma reflexão sobre a natureza da Ordem e do apostolado missionário. Ela nos lembra que as atividades intelectuais e as ligadas às ciências não são constitutivas da identidade jesuíta, mas um elemento contingente da mesma, devido às interpretações abertas do princípio inaciano de atuar no século. Segundo ela, as atividades da Companhia exigiam, sim, "competências científicas", tanto aquelas que a Ordem viesse a solicitar explicitamente, quanto as que os missionários viessem a acionar nos marcos de seu apostolado. ${ }^{16}$

9 Segundo o historiador Thomas Haddad, o "conhecimento natural ou missiológico, práticas e saber-fazer, nada disso escapou à 'efervescência' das 'zonas de contato'. ${ }^{17}$ As ideias introduzidas pelos europeus foram modificadas, as estratégias missionárias se desviaram dos planos traçados em Roma, sob os imperativos de uma 'ortopraxis' que escapa à ortodoxia, como destacado por Nicola Gasbarro, ${ }^{18} \mathrm{e}$ as informações 'coletadas' localmente e remetidas à Europa já carregavam a marca dos informantes locais, dos intermediários, de seus sistemas de classificação e de valoração do mundo". ${ }^{19} \mathrm{O}$ 
conhecimento moderno, segundo Haddad, "pode ter sido produzido em todo lugar, por uma multiplicidade de agentes, intermediários, facilitadores, informantes, todos envolvidos em trocas e negociações constantes, locais e globais, sempre assimétricas e marcadas pela violência, mas ainda assim relacionais". Nessas trocas e negociações é que teria se constituído "a modernidade global, inclusive em termos da ciência, e não isoladamente nas instituições europeias" ${ }^{20}$

No que se refere especificamente ao apostolado na América portuguesa e na espanhola, é preciso considerar que os missionários se defrontaram com questões que tiveram de ser resolvidas localmente, e que deste processo de contato resultaram alterações em suas concepções teológicas e científicas - com as quais, seguramente, entraram em contato durante seu período de formação -, que não puderam escapar à efervescência do contato, como proposto por Zupanov. ${ }^{21}$ Pode-se, assim, pensar que muitos jesuítas estiveram bem "longe da imagem estereotipada e triunfal do jesuíta-erudito", que difundiu pelo mundo "as últimas novidades da ciência européia", estando muito mais próximos do "missionário típico", que precisava enfrentar "os problemas concretos da alteridade, da conversão e da própria construção dos impérios com o material que tinha efetivamente à sua disposição". ${ }^{22}$ Este aspecto é também ressaltado por Millones Figueroa e Ledezma, para quem, apesar de a Historia Natural y moral de las Índias, de José de Acosta (1590) expressar com clareza "el benefício de la escritura naturalista" e ser um modelo a ser seguido,

las experiencias de cada jesuíta fueron muy distintas, y quienes se aventuararon en la escritura tenían muchas veces una geografia, flora y fauna nueva que presentar, explicaciones que proponer (...) y, acaso lo más importante, dirigir el placer y la admiración hacia la alabanza de Dios. ${ }^{23}$

11 No século XVIII, os jesuítas abandonaram "los argumentos de la naturaleza maravillosa, llena de portentos y señales (...) para iniciar la formulación de un pensamiento ilustrado y crear sus propias nociones etnográficas y científicas del mundo americano" e esta mudança de percepção do mundo natural se constituiu em "medio a través del cual los jesuítas expulsos subrayan su control y posesión intelectual" das regiões em que atuaram e das populações indígenas que converteram ou conheceram como missionários. ${ }^{24}$ Para Kristin Huffine, "los padres jesuítas del Paraguay, en sus historias naturales, señalaron una pauta en la creación de un conocimiento científico americano, basado en la observación de los hechos y en una interpretación que decididamente pretendía ser objetiva", o que fazia com que se opusessem a um conhecimento produzido sobre o Novo Mundo na Europa da Ilustração, "que carecía del fundamento de la observación y de la experiencia" e, especialmente, à tese de inferioridade natural do Novo Mundo. ${ }^{25}$ Também para Miguel de Asúa, os os trabalhos de ciência jesuíta produzidos no exílio procuraram argumentar contra "la tesis de la inferioridad de la naturaleza del nuevo mundo, avanzada por Buffon y expandida por Cornelius de Pauw en sus Recherches philosophiques sur les Américains, publicado en Berlín entre 1768 y 1769". ${ }^{26}$

12 Já Sabine Anagnostou e Fechner, além de destacarem que a obra do padre José Sánchez Labrador pode ser considerada como "la culminación de la historia natural de los jesuítas en el Paraguay", observam que se, por um lado, "a história natural e a farmácia missioneira podem ser consideradas as duas facetas principais do naturalismo jesuítico na América do Sul", por outro, não devem ser percebidas como "precursoras deficientes das ciências atuais ou como cópias insuficientes dos modelos europeus, mas como formas independentes e singulares da história da ciência". ${ }^{27}$ Esta singularidade, segundo os 
autores, fica evidenciada na "experimentação e na incorporação do saber etnofarmacêutico indígena", que decorreu da "posição relativamente imparcial e aberta dos jesuítas frente aos indígenas, baseada na espiritualidade inaciana", que possibilitou "um intercâmbio intenso e persistente no campo da medicina". ${ }^{28}$

Para outros estudiosos da produção do jesuíta Sánchez Labrador, ele pode ser considerado "un paradigma de toda aquella generación" de missionários jesuítas que atuaram na América platina no século XVIII, não apenas por seu extenso conhecimento da área missioneira, mas porque "nada escapó a su curiosidad, desde el clima, la geología, la botânica o la zoologia". ${ }^{29}$ No exílio, adotou certa visão científica "en el sentido moderno de la palabra (...) una noción dinámica de las ciencias", e, com "un vigor ilustrado", descreveu "la naturaleza como objeto útil y detalladamente clasificable por la investigación", a partir de "una idea clara del progreso en las ciencias". ${ }^{30} \mathrm{Em}$ razão disso, a reconstituição das trajetórias de jesuítas, que se dedicaram à ciência, como Sánchez Labrador, e a análise de obras como o Paraguay Natural Ilustrado, ${ }^{31}$ escrita por ele entre os anos de 1771 e 1776 - e que apresentamos e analisamos neste artigo -, permite, não apenas a reconstituição do conhecimento científico difundido e produzido nas primeiras décadas do século XVIII na América, ${ }^{32}$ mas também a discussão sobre a apropriação de saberes e de práticas das populações nativas americanas, que pode ser constatada nos receituários e nos catálogos de plantas medicinais que os missionários da Companhia de Jesus fizeram e que circularam nos continentes em que atuaram. ${ }^{33}$

14 É sobre a trajetória deste jesuíta e sobre o Paraguay Natural Ilustrado que nos deteremos na continuidade, levando em consideração tanto o contexto de sua produção, primeiramente, na América, e, posteriormente, na Europa de seu exílio, quanto à influência dos aspectos próprios da cultura escrita e científica da Companhia de Jesus, que apresentamos e discutimos no primeiro tópico.

\section{Sobre o autor e o manuscrito}

15 José Sánchez Labrador nasceu em La Guardia, na província de Toledo, no dia 19 de setembro de 1717 [ou 1714] ${ }^{34}$ e morreu em Ravena, em 10 de outubro de 1798. Ingressou na Companhia de Jesus em 5 de outubro de 1731, de acordo com Ruiz Moreno (1948), ou em 19 de setembro de 1732, segundo Sainz Ollero et al. (1989), ${ }^{35}$ tendo cursado Gramática e Humanidades. Iniciou seus estudos de Filosofia no Noviciado de San Luis de Sevilha, interrompendo-os para viajar ao Rio da Prata em 1733, acompanhando o Padre Procurador Antonio Machoni. De 1734 a 1739, estudou Filosofia e Teologia na Universidade de Córdoba, concluindo sua formação no verão de $1739 .{ }^{36}$ De acordo com seus biógrafos, entre os anos de 1741 e 1746, atuou como professor na mesma cidade, dedicando-se, concomitantemente, aos estudos de História Natural. ${ }^{37}$

16 Assim, como muitos outros padres e irmãos jesuítas que o precederam nas terras de missão americanas, Sánchez Labrador não se dedicou, exclusivamente, à conversão dos indígenas, mas também ao estudo da fauna e da flora americana que observou nas diversas regiões da Província Jesuítica do Paraguai em que atuou como missionário. ${ }^{38}$ De acordo com alguns de seus biógrafos, entre 1747 e 1767, o padre jesuíta atuou junto às reduções de San Francisco Xavier, Santa Maria la Mayor, La Cruz, Santo Thomé e San José. ${ }^{39}$ A partir de 1757, passou a atuar em Apóstoles (Santos Apóstolos ou Apóstolos São Pedro e São Pablo), tendo como companheiros os padres Lorenzo Ovando e Segismundo Asperger, este último, reconhecido por sua atuação como médico e boticário. Sabe-se que, 
dois anos depois, lecionou Teologia no Colégio de Assunção, e que no ano seguinte (1760), missionou entre índios Mbayás e Guaranis, que, mais tarde, formariam a redução de Nuestra Señora de Belén, e entre os índios Guanas, com os quais criou a redução de San Juan Nepomuceno. Em 14 de agosto de 1767, logo após seu regresso de uma viagem às missões de índios Chiquitos, ${ }^{40}$ Sánchez Labrador foi informado do decreto da expulsão ${ }^{41}$ dos jesuítas da Espanha e de suas colônias. Em $1768,{ }^{42}$ chegou à Itália, se estabelecendo em Ravena, onde foi Superior de uma das casas que a Companhia de Jesus possuía na cidade. Manteve-se neste desterro por 30 anos ${ }^{43}$ período durante o qual se dedicou a escrever suas principais obras: o Paraguay Católico, o Paraguay Cultivado e o Paraguay Natural Ilustrado. ${ }^{44}$

17 Esta última já mereceu alguns estudos, realizados a partir da consulta à versão manuscrita (que não foi ainda integralmente publicada) ${ }^{45}$ que se encontra no Archivo Romanum Societatis Iesu - ARSI (Roma), dentre os quais destacamos os de G. Furlong, Naturalistas Argentinos durante la dominacion Hispânica (1948); de A. Moreno, La Medicina en "el Paraguay Natural” (1771-1776) del P. José Sánchez Labrador S. J.: Exposición comentada del texto original (1958); e o de Sainz Ollero et al. José Sánchez Labrador y los naturalistas jesuitas del Río de la Plata (1989). Estes historiadores ressaltam que o jesuíta "realizou um dos mais amplos trabalhos sobre a natureza, a geografia e as sociedades da região platina colonial", permanecendo, no entanto, "dúvidas sobre a forma como redigiu tão vasta obra", cogitando-se que tenha "conseguido levar muitos apontamentos feitos na América" e que "mesmo que o tivesse feito, o mais provável é que tenha sido obrigado a escrever a maior parte da obra de memória. ${ }^{46}$

Dentre os inúmeros fatores que podem justificar a não publicação do manuscrito Paraguay Natural está, sem dúvida, o número total de páginas dos seus quatro tomos, ${ }^{47} \mathrm{a}$ lentidão dos trâmites burocráticos de censura editorial (civis e eclesiásticos) e os custos de impressão. A obra é composta de quatro Partes ou Tomos, sendo que a Parte Primera conta com os Livros: I. Diversidad de Tierras, y Cuerpos terrestres; II. Agua, y varias cosas a ella pertenecientes; III. Ayre, Vientos, Estaciones del Año, Clima de estos Países, y Enfermedades mas ordinarías; a Parte Segunda, os Livros: I. Botanica, o de las Plantas en general; II. Selvas, Campos, y Pradarias del Paraguay; III. Los Arboles en particular; IV. Palmas, Tunas, y Cañas; V. Ycipos, y otras Plantas Sarmentosas; VI. Algunos Arbolillos, Matorrales, y Hierbas; VII. Algunos útiles, y curiosos usos, escritos em 1772; a Parte Tercera ${ }^{48}$ possui os Livros: I. Animales Quadrupedos; II. Las Aves; III. Los Peces, elaborados em 1771, e a Parte Quarta, os Livros: I. De los Animales Amphybios; II. De los Animales Reptiles; III. De los Insectos, que foram concluídos no ano de 1776, além das 127 ilustrações feitas pelo próprio autor. ${ }^{49}$

Não se deve desconhecer, também, que em 1776, ano de sua conclusão, a Companhia de Jesus ainda não havia sido restaurada, o que irá ocorrer somente em 1814, o que, certamente, contribuiu para que a volumosa obra se mantivesse desconhecida dos pesquisadores por muitos anos. Ao longo do século XX, alguns autores, como José Luis Molinari (1938), Guillermo Furlong (1948), Aníbal Ruiz Moreno (1958), Hector Sainz Ollero, Hélios Sainz Ollero; Francisco Suárez Cardona; Miguel Vázquez de Castro Ontañón (1989) e Mariano Castex (1963), se limitaram a fazer publicações parciais de certos tomos, livros e capítulos do Paraguay Natural Ilustrado, sendo que, na maioria das vezes, não indicaram as referências completas dos excertos selecionados.

20 A transcrição e a leitura dos volumosos tomos da obra do missionário José Sánchez Labrador nos revelam também muito sobre suas motivações, sobre seu processo de 
criação (as técnicas e o estilo), ${ }^{50}$ sobre sua escrita em meio à convivência diária com os indígenas e em um contexto bastante peculiar para a Companhia de Jesus, sobre o diálogo mantido com outros autores e com outros jesuítas e, ainda, sobre os efeitos da memória que se manifestam nas rasuras feitas no corpo do texto, ou nas anotações complementares inseridas nas margens ou nas notas de pé de página, ${ }^{51}$ que, muito mais do que erudição, nos mostram "las características del libro de autor", na expressão do historiador argentino Silvano Benito Moya. Um livro de autor, "es decir, de su puño y letra, con las cavilaciones, enmiendas, agregados, testados que el autor haya realizado em su ejemplar autógrafo". ${ }^{52}$ É plausível supor que o Paraguay Natural tenha sido escrito, assim como tantos outros produzidos por irmãos e padres jesuítas na América ou na Europa, com "lapiceras de acero y con tinta negra (...) de composición metálica", em "celdas veraniegas, o en las caminatas vespertinas para despejar la mente", pois era nelas que "transcurría la vida interior de los autores, sus especulaciones y dudas, consultando la bibliografia y luchando con su pluma". ${ }^{53}$

21 A tradição de copiar à mão constituiu um fenômeno com largo êxito até tempos relativamente recentes (meados do século XIX, na Europa) e a "facilidade e economia do acto de copiar muito contribuíram para uma dinâmica circulação de manuscritos, que o advento da tipografia não poderia, obviamente, demolir", uma vez que, mesmo depois do incremento das tiragens e da consequente diminuição de custos, essa "cultura dos escribas" e essa tradição de utilizar o manuscrito como principal instrumento de divulgação de saberes coexistiram com a difusão dos impressos, como bem observado por Bouza (2001)..$^{54}$

Ao longo dos capítulos, encontramos indícios que demonstram que Sánchez Labrador concebeu as três obras interligadas e complementares. Pode-se dizer que o procedimento de divisão e sistematização dos conhecimentos e estudos sobre a Província Jesuítica do Paraguai, empregado pelo jesuíta não era novo e, também, não estava dissociado do contexto em que as escreveu. Michel de Certeau (2011) nos fala sobre as mudanças decorrentes do advento da sociedade moderna, que teriam causado uma diferenciação epistemológica e social que implicou numa divisão no trabalho da escrita, especialmente, na escrita dos relatos de viagem que tratavam das descrições do contato do homem selvagem com a tradição religiosa cristã. Certeau chama também a atenção para outro recurso, a diferenciação feita entre o sujeito e o objeto etnológicos, utilizado pelos autores dos séculos XVI, XVII e XVIII quando descreviam o Novo Mundo e de suas particularidades: "No texto, ela é traçada pela diferença entre duas formas literárias: a que conta viagens; a que descreve uma paisagem natural e humana". ${ }^{55}$ É bastante claro que Sánchez Labrador faz uso dessa configuração para organizar suas obras, como se fizessem parte de um todo já planejado. Assim, ele destinou o Paraguay Católico, publicado em dois tomos, somente em 1910, para apresentar um estudo etnográfico, privilegiando os relatos das viagens que empreendeu e sua relação com os grupos indígenas e com os demais habitantes do Paraguai, não se aprofundando tanto nas descrições da natureza. O jesuíta optou por destinar as descrições e apontamentos relativos à História Natural, com informações sobre botânica, zoologia, geologia e agricultura para o Paraguay Cultivado e para o Paraguay Natural Ilustrado. Em relação ao Paraguay Cultivado, cujo manuscrito encontra-se perdido, ${ }^{56}$ sabe-se que seus quatro tomos tratavam de aspectos relativos às atividades da agricultura e da pecuária praticadas na Província Jesuítica do Paraguai, ${ }^{57}$ o que pode ser confirmado na Introdução do Segundo Tomo da obra Paraguay Natural Ilustrado, quando Sánchez Labrador, a tratar 
da divisão proposta por alguns estudiosos entre uma botânica prática e outra especulativa, menciona que:

(...) algunos principios concernientes al cultivo, y labor de las Plantas, mas esto se hace como de pajo, reservando para otra obra, cuyo Primer Tomo, tengo ya escrito, el tratar de propósito de una materia tan importante, la qual se intitula, Paraguay Cultivado. ${ }^{58}$

23 A afirmação que transcrevemos acima confirma que para Sánchez Labrador as três obras se complementavam, oferecendo aos potenciais leitores um amplo e diversificado estudo sobre o Paraguai.

Quanto à organização da obra, feita por Sanchez Labrador, é importante ressaltar que o autor continuamente corrige erros; reescreve trechos ou frases completas; risca certas palavras; adiciona palavras e trechos ao texto; e chama atenção para outras partes da própria obra ou de outras de suas produções (como o Paraguai Católico ou o Paraguai Cultivado). ${ }^{59}$ Quando sente necessidade, o jesuíta faz adições no texto se utilizando de um símbolo muito semelhante à uma "Cruz de Malta", indicando onde cada trecho deve ser colocado, sendo que estas adições podem estar presentes nas margens das páginas, nos rodapés e até em outras folhas que são marcadas com a página em que o trecho deve ser acrescentado. Estas “correções” ou "adições” no texto do Paraguay Natural Ilustrado indicam um grande cuidado do autor na escrita da obra, bem como o fato de ele revisar o que já foi feito.

Em algumas situações são claras as interferências de terceiros - não o autor - no manuscrito, sendo adicionados números, linhas ou anotações. Isto pode ser encontrado principalmente nos Índices de todos os quatro tomos da obra em que estão assinaladas não somente os números das páginas dos capítulos de acordo com Sanchez Labrador, mas também de acordo com a numeração do arquivo ${ }^{60}$ em que o manuscrito se encontra.

A cada página do manuscrito o autor reinicia a contagem de suas notas de rodapé, ou seja, em cada página temos novamente as notas contadas desde o número "1". Em algumas situações Sanchez Labrador corrige suas notas de rodapé; muda a ordem de numeração; risca notas; acrescente algumas posteriormente mudando a ordem numérica das notas na página; deixa notas em branco; coloca o número da mesma nota em locais diferentes do texto; faz notas de rodapé e não as numera no texto; coloca duas vezes a mesma nota no rodapé; e pula a numeração das notas.

Quanto aos desenhos feitos por Sanchez Labrador, eles são normalmente colocados em folhas separadas do texto, cada imagem em uma página da folha, ou um desenho por folha. As folhas de desenhos, geralmente, contêm os números das páginas da obra às quais seus desenhos se referenciam. No caso do Tomo II, as imagens são adicionadas no meio das páginas escritas, sendo estas representações de plantas que estão sendo tratadas no texto. No Tomo III, as imagens desenhadas estão ao final de cada um dos três livros pertencentes ao tomo. Enquanto que no Tomo IV, as imagens são inseridas no final dos três livros, mas são relacionadas com todo o tomo. Nos casos destes dois tomos, o III e o IV, as imagens não recebem numeração, então não se pode afirmar corretamente a que livro, capítulo ou página cada uma delas pertence. No Paraguay Natural Ilustrado encontramos 127 desenhos feitos pelo próprio autor, sendo que o Tomo II conta com 105, o Tomo III possui 13, e, o Tomo IV, 9 imagens, sendo que o Tomo I é o único dos quatro que não possui quaisquer ilustrações. Em situações mais raras, o jesuíta insere alguns desenhos no meio das páginas escritas, às vezes, no início das páginas ou, até mesmo, no meio do texto. Diferentemente dos 127 já referidos, estes não serviam para ilustrar as 
plantas, animais, práticas ou elementos sobre os quais Sánchez Labrador escrevia, mas, sim, para contribuir com alguma explicação do autor, por essa razão, esses desenhos, normalmente, possuem um nome e uma espécie de legenda que explicam do que se trata. Exemplo disso pode ser encontrado no sétimo livro do Tomo I $^{61}$ da obra, onde Sánchez Labrador, ao falar sobre vernizes, insere um desenho de um "Quadrangulo" no qual eram postas as lâminas de madeira, ou telas, para terem suas duas superfícies envernizadas.

O volumoso manuscrito, como os leitores poderão constatar na análise que apresentamos na continuidade, oferece inúmeras possibilidades de investigação aos pesquisadores dos campos da História, da Biologia (Botânica e Zoologia), da Medicina e da Farmácia. Dentre elas, destacamos, primeiramente, partes específicas dos três livros do Primeiro Tomo, no qual o jesuíta aborda certas práticas adotadas por mulheres indígenas, as virtudes medicinais de alguns tipos de terras encontradas na Província do Paraguai, algumas informações sobre as águas, as quais ele relaciona com a saúde, e, também, o segundo subcapítulo do capítulo IX, do Livro Três, que trata unicamente sobre as enfermidades mais comuns da região. O Segundo Tomo da obra, que trata sobre Botânica, é a parte que traz o maior número de informações e referências sobre virtudes medicinais, contando com inúmeras referências a autores e a obras de medicina, e, em seus primeiros seis livros, isso fica bastante presente. Dele, destacamos os Livros Três e Seis - que tratam sobre as árvores e as ervas do Paraguai, respectivamente -, nos quais Sánchez Labrador se detém nas virtudes de determinados bálsamos extraídos dos troncos das árvores e nas práticas terapêuticas que certos grupos indígenas faziam no tratamento de enfermos. 0 Primeiro Livro da Terceira Parte da obra - dedicada aos Mamíferos -, no qual encontramos o Livro Animais Quadrúpedes. O sétimo capítulo trata, especificamente, das Pedras Bezoares e de suas virtudes terapêuticas, na medida em que aparecem associados aos animais ruminantes. Já no Terceiro Livro da Quarta Parte da obra, o autor trata d "Os Insetos", sendo que no último capítulo, aborda a utilidade dos insetos na Medicina, dentre os quais se encontram os escorpiões, as aranhas, os percevejos, os besouros, os grilos, as formigas, as moscas, os piolhos e as sanguessugas. Interessante observar que na documentação jesuítica são recorrentes as menções a acidentes com animais venenosos, como serpentes, escorpiões e aranhas, que podem ser atribuídas tanto ao ambiente natural em que as reduções se estabeleceram, quanto a desordens climáticas, tais como secas ou enchentes, que podem ter favorecido a sua proliferação ou deslocamento para outras regiões. ${ }^{62}$

\section{Sobre a Parte Primera}

Esta Parte possui 558 páginas, sendo a maior de todas, e divide-se em três Livros: Diversidade de terras e corpos terrestres; Água e várias coisas a ela pertencentes; e Ar, ventos, estações do ano, clima destes países e enfermidades mais comuns. O Primeiro Livro dessa parte da obra conta com 28 capítulos, o Livro II com 10 capítulos e o Terceiro Livro com 10 capítulos mais uma seção final somente com curiosidades que o autor julgou importante adicionar.

No Primeiro Tomo, Sánchez Labrador trata das utilidades e virtudes terapêuticas de elementos como a terra e a água, apresentando, também, sua concepção de História Natural, como se constata nesta passagem extraída da Introdução:

Si la Historia natural es universal, espressa un conocimiento, y la descripción de todos los seres, y cosas, que componen el universo, quanto en si es. La historia delos 
cielos, de la Atmosphera, de la Tierra, de todos los phenomenos, que acontencen en el mundo, y aun la del mismo Hombre. ${ }^{63}$

31 No parágrafo seguinte, o autor não apenas explica melhor sua concepção de História Natural, como informa o leitor sobre as razões da escrita do Paraguay Natural Ilustrado. Deixa claro que sua intenção era a de produzir um trabalho de História Natural sobre a região do Paraguai, e que, apesar desta delimitação, tratava-se de um estudo complexo: "Es verdad, que aun la História Natural de un solo País es un sugeto de bien basta extensión, por lo respectivo a sus materiales: por lo que en su descripción se hace indispensable grande cuidado, y circunspección en la pluma". ${ }^{64}$ Neste mesmo trecho, ele ressalta o que viria a reafirmar na Introdução do Tomo de Botânica, isto é, que os trabalhos até então produzidos sobre a natureza do Paraguai não haviam sido capazes de abranger todos os pontos necessários, sendo indispensável a produção de uma obra que alcançasse tal propósito:

Nuestro empeño no se puede extender, por falta de Talento, a tanta universalidad; nos hemos ceñido a ilustrar la Naturaleza de un País, tan poco conocido por sus producciones naturales, quanto preconizado por otros títulos, que por ahora no hacen al intento. ${ }^{65}$

No Primeiro Livro, intitulado Diversidad de Tierras, y Cuerpos terrestres, Sánchez Labrador refere as virtudes medicinais de determinados tipos de terras que se encontravam na região da Província Jesuítica do Paraguai. A primeira sobre a qual o autor trata é a Terra Marga, que, segundo sua descrição, seria:

La Marga es una especíe de Tierra fossil, y como la substancía de la tierra misma, que fecunda, y abona marabillosamente aun los suelos mas esteriles. Por lo comun se halla debajo de tierra, de modo, que es menester cavar quatro, o cinco toesas para encontrarla, pero una vez hallada, suele seguir su beta por muchas baras. ${ }^{66}$

Para falar sobre as virtudes terapêuticas desse tipo de terra, o autor recorre aos autores Robert James ${ }^{67}$ e Nicolás Lemery, ${ }^{68}$ que teriam atribuído a ela virtudes detersivas, adstringentes, dessecantes e narvóticas [sic], pois "faziam crescer as carnes" e resolviam o sangue "coalhado", podendo ser usadas internamente e externamente.

Outra terra muito destacada por suas virtudes no Paraguay Natural Ilustrado é a Greda, que o autor explica ser uma espécie de argila abundante nas terras do Paraguai e muito conhecida pelos grupos indígenas com os quais o jesuíta teve contato. Para Sánchez Labrador, "La Greda es, pues, una tierra calcaría, friable, harinosa, privada de sabor, y de olor, comunmente blanquecina, compacta, calcinable, y que recibe los acidos, asi vegetables, como minerales; estiendese considerablemente en el agua, y atrahe grandemente la humedad dela Atmosphera". ${ }^{69}$ Segundo o jesuíta, existiam vários tipos de greda, que podia ser considerada uma "terra primitiva". As virtudes medicinais dessa terra seriam inúmeras, podendo ser utilizada externamente, pois somente a espécie chamada de Greda Branca poderia ser ingerida internamente:

La Greda blanca es alcalina, detersiva, disecante, y absorvente. Administrase interiormente despues de bien lavada, para endulzar los acidos del estomago, y del pecho: también para la salivación de sangre, para la disentería, y para otras evacuaciones violentas. La dosis es desde medío escrúpulo hasta dos escrúpulos. ${ }^{70}$

35 No geral, a greda teria propriedades resolutivas, dessecantes e adstringentes e, quando aplicada externamente, mesclando-se essa terra com emplastos e unguentos, seria própria para deter o sangue de feridas. Misturada com licores e colocada para ferver, a greda poderia ser utilizada para uma série de males, especialmente, por ser uma terra alcalina e absorvente. Nesse sentido, teria como qualidade particular a função de absorver 
os ácidos ou moderá-los, reprimindo, assim, o movimento violento do humor chamado de Biles, atuando nos problemas do estômago. Além dessas utilidades medicinais, Sánchez Labrador diz, ainda, que a greda "Ayuda particularmente en aquellos males llamados Palpitación del corazon; en las Toses, que nacen de la flema acrimonosa, o salada; y se dice, que mata las Lombrices, y Gusanos". ${ }^{71}$

Neste Primeiro Livro do Tomo da obra, no capítulo três do Livro I, intitulado Nuevos Pobladores del Paraguay, o jesuíta descreve os diferentes povos que ocupavam a Província do Paraguai, enfocando, de forma bastante científica e descritiva, a cor de pele dos indivíduos negros e dos povos indígenas, e estabelecendo comparações com o que outros autores escreveram sobre os nativos das Filipinas. Neste mesmo capítulo, encontramos referências a práticas de controle de natalidade e ao aborto praticado entre os índios Mbayas:

Los Auctores, que escriben de la Isla Formosa, aunque difieren notablemente en la descripción tocante a la physonomía, y figura de estos isleños, convienen en un hecho bien extraordinarío, sino tuviera semejante en la America en la Nación Mbaya, y otras de acaballo, en la tal isla no se permite parir a las mugeres antes de los treinta años de su edad, bien que a las mismas les es libre el casarse mucho tiempo antes de esa edad. Quando estan en cinta, las sacerdotisas (entre los Mbayas ciertas Parteras) van a apretarles, y aporrear el vientre con los pies (entre los Mbayas) con las manos, y piedras) para hacerlas abortar. ${ }^{72}$

Como o Paraguay Natural Ilustrado, segundo o próprio Sánchez Labrador, se propunha a ser uma obra de História Natural, não são frequentes as passagens em que o autor aborda a organização social desses grupos ou as práticas adotadas pelas mulheres indígenas. Entretanto, outros jesuítas e viajantes puderam observar essa mesma prática de aborto entre as índias Mbayas, como Félix de Azara, autor da obra Viajes por la America Meridional, publicada em 1809. Nessa obra, o militar espanhol relata que havia observado a seguinte prática entre as índias Mbayas: ${ }^{73}$

En seguida se tendió de espaldas en el suelo, completamente desnuda, y dos viejas empezaron a darles sobre el vientre golpes muy violentos hasta que empezó a salir sangre; tal fue el preludio del aborto, que se verificó el mismo día. También supe que algunas quedaban lastimadas para el resto de su vida y que otras se morían. ${ }^{74}$

Além de considerá-la bárbara, Azara entendeu que esta prática era uma das causas do gradual desaparecimento dos povos Mbayas. De acordo com ele, a interrupção da gestação estava relacionada com a manutenção da saúde feminina, pois segundo as próprias indígenas, as sucessivas gestações debilitavam seus corpos:

Cuando damos a luz en su tiempo completo, esto nos estropea, nos deforma y nos envejece, y vosotros los hombres no nos queréis en este estado; además, nada más engorroso para nosotros que criar los niños y llevarlos en nuestras diferentes marchas, en las que con frecuencia nos faltan víveres; esto es los que nos ha decidido a provocarnos el aborto en cuanto nos sentimos embarazadas; porque nuestro fruto, siendo entonces más pequeño, sale con más facilidad. ${ }^{75}$

Também o irmão jesuíta Pedro Montenegro, que atuou como missionário na Província do Paraguai no século XVIII, confirma a prática do aborto entre as populações indígenas, ao referir, em sua obra Materia Medica Misionera (1710), a utilização de certas plantas com esta finalidade, como o Dictamo “(...) que el Indio llama Caáberá miri, y guazú pucú caá (... ) El cocimiento del Dictamo bebido acelera el parto, y saca la criatura muerta, asi bebido como dado por perfume, ó su zumo aplicado á la boca de la matriz". ${ }^{76}$ 
Já no Segundo Livro do Primeiro Tomo do Paraguay Natural Ilustrado, intitulado Agua, y varias cosas a ella pertenecientes, o jesuíta trata, principalmente, das águas do Paraguai, de seus rios e lagos, mas sempre com um foco maior nas utilidades que tinham para as populações que viviam nessas regiões. Se para Sánchez Labrador, a água em excesso e a falta de água causavam problemas, ele não descuidada de ressaltar as qualidades e a importância da água dos rios:

Nuestras moradas son enfermizas, ò quando las aguas estancadas, y retalfadas causan una humedad continua, y excesiva; ò quando la falta de agua nos dà una sequedad dañosa. Los rios, aun los medianos refrescan el ayre del territorio vecino, esparcen en el suave rocios, y purifican la tierra de quanto la pude infestar. Limpian tambien el ayre las aguas vivas, y corrientes; y con sus quotidianos vapores le obligan à mudar de sitio, y à que no se corrompa, ni comun que contagio alguna, deteniendose, siempre en un mismo parage..$^{77}$

41 Os lagos que atravessavam os rios Paraná, Uruguay, Paraguay, Bermejo, Pilcomayo e outros teriam, segundo ele, boas qualidades, porque purificavam tanto as águas, quanto o ar. Afirma, ainda, que os índios Mbayas e outras Nações Infiéis teriam conhecimento disso, passando determinado tempo próximo aos lagos e, por essa razão, viviam sãos, gozando de boa saúde.

Sánchez Labrador defende, ainda, que nadar e banhar-se eram atividades recomendadas para assegurar boa saúde. Muitos médicos antigos e modernos, segundo ele, indicavam a combinação do exercício com o contato do corpo com a água fria:

Efectivmente parece cosa indubitable, que fuera dela accion de los musculos en casi todas las partes del cuerpo, que se hace en esta especie de exercicio, como en otros muchos, la aplicación dela agua fría, dentro dela qual se nada, contribuye, no solo con su peso sobre la superficie del cuerpo, mas tambien por su qualidad fria la qual no dexa de ser tal atendida la contigua mutacion, que se hace delas superficies del fluido ambiente, contribuye, digo, à condensar, y fortificar las fibras, y à acrecentar la elasticidad de estas, y hacer su accion mas eficaz sobre los fluidos; de los quales impide tambien la dissolucion, y el demasiado enervamiento, y disipación (...). ${ }^{78}$

Ele não deixa, no entanto, de chamar a atenção para certos perigos no consumo de determinados tipos de águas, como as congeladas, que "caem do céu" e, que, na opinião de algunos, provocava "(...) la inflamacion del cuello, que llamamos, Papada".79

Do terceiro e último livro deste mesmo Tomo I, chamado Ayre, Vientos, Estaciones del Año, Clima de estos Países, y Enfermedades mas ordinarías, destacamos o segundo subcapítulo do Capítulo IX, que trata exclusivamente das enfermidades mais comuns na Província Jesuítica do Paraguai. Elas decorriam, segundo Sánchez Labrador, do clima quente e úmido do Paraguai, que, segundo ele, se encontrava na "Zona Torrida", o que causaria alteraç̃oes nos humores do corpo humano. Os "forasteiros" seriam os mais suscetíveis às doenças, principalmente, dos males do fígado e de "esponjamento" da carne, devido a uma diminuição ou obstrução da transpiração decorrente do "engrossamento dos humores". O jesuíta recomendava que tanto os forasteiros, quanto os espanhóis que viviam no Paraguai deveriam proteger cuidadosamente os poros do corpo, cobrindo os pés durante a noite, para que a temperatura corporal não se alterasse, provocando a enfermidade.

45 Essa preocupação de Sánchez Labrador com a falta de transpiração, e o desequilíbrio dos humores, se relaciona com o fato de o jesuíta compreender as doenças e também as terapêuticas com base no pressupostos da Teoria humoralista hipocrático-galênica, ainda vigente no período em que o autor escreveu a obra. Segundo essa teoria, a saúde era 
assegurada pelo equilíbrio entre os humores que compunham o corpo humano. ${ }^{80}$ Desta forma, existia a concepção de que as enfermidades eram causadas justamente pelo excesso ou ausência de algum dos humores: "Se a saúde assentava no equilíbrio, a doença era, em primeiro lugar, desequilíbrio, devido ao excesso de um dos elementos constituintes do corpo, ou a um excesso de calor, de frio, de secura ou de humidade". ${ }^{81}$ Como as doenças eram, normalmente, causadas pelo excesso desses humores, as práticas medicinais relacionadas com esta teoria tinham como objetivo a expulsão dos maus humores através do sangue, das fezes, da urina, da transpiração, do vômito e de demais formas de excreção. Por esta razão, eram largamente utilizadas na Europa as práticas terapêuticas de purgar, fazer sangrias, causar vômitos e provocar urina. Por essa razão, Sánchez Labrador entendia como muito preocupante o impedimento da transpiração no corpo humano, pois seria através dela que o corpo se livraria dos maus humores e, caso fosse obstruída, esses humores poderiam se acumular no corpo e causar doenças:

(...) si la transpiración, o copiosa en sudor, o menos sensible está libre, no molesta a la salud: pero si se impide, y el cuerpo no se desfoga por los poros, se experimenta pesadez, la qual indica matería, que en breve se dara a conocer en una enfermedad fuerte. ${ }^{82}$

No terceiro livro do Tomo I da obra, o jesuíta faz, também, uma série de recomendações para os que viviam no Paraguai, tais como a de não consumir nada nem muito quente e nem muito frio, uma vez que as coisas quentes em excesso causariam, segundo ele, “(...) caimiento, desmayos, afeminan los cuerpos, que quedan en una laxitud deplorable, sin color, ni fuerzas, por la dissipación abundante de los espiritus vitales". ${ }^{83}$ Já a preocupação com o consumo das coisas frias seria porque elas causariam "(...) entorpecimiento delos miembros, obstrucciones, reprimiendo hacía adentro la matería, que debía transpirarse". ${ }^{84}$ Também recomenda que exercícios deveriam ser praticados logo cedo pela manhã ou no final da tarde, para que as pessoas não tomassem muito sol e, também, para que o ar do Paraguai não aumentasse ou causasse ardor nos "espíritos" e nos humores do corpo. De qualquer modo, o autor diz que trabalhos e exercícios extremos não seriam positivos para a saúde, ao mesmo tempo em que deixar de dormir também não faria bem, principalmente, para a cabeça.

47 O autor fala ainda sobre a importância do aproveitamento das frutas existentes no Paraguai, que deveriam ser ingeridas principalmente pela manhã, pois fariam muito bem para a saúde. Mas faz críticas ao consumo de Aguardiente e de Ponche, dizendo que causavam problemas àqueles que os ingerissem em excesso:

(...) que la bebida del Aguardiente (...) les acarrea muchos males, usada con nimiedad, y frequencía. Su uso ca siempre acompañado de tristes, y desgraciados efectos: porque sutiliza, y extenua el cuerpo; disminuye, y quita las fuerzas; entorpece, y ofusca el celebro. ${ }^{85}$

Apesar de destacar os males da bebida e de deixar claro que estavam mais suscetíveis às doenças aqueles que se entregavam aos deleites de Baco e Vênus, o jesuíta também condena as abstinências, por afirmar que ficar muito tempo sem comer, dormir e beber também acarretaria grandes prejuízos à saúde, especialmente, para os que teriam problemas com a bílis e com a cólera. Ao falar sobre a ingestão de vinho, Sánchez Labrador afirma que o francês seria melhor do que o produzido na Espanha, e que deveria ser ingerido em quantidade moderada, pois "Cometen un grande error contra sus vidas los que le beben en mayor abundancía delo que conviene en estos temples calientes". ${ }^{86}$

O jesuíta também escreveu sobre as doenças de verão, as doenças de inverno e as epidemias e viroses. Sobre as doenças de verão, ele afirma que são causadas pelo clima 
mais seco desse período e que seriam menos prejudiciais e mais fáceis de curar do que as de inverno, que eram causadas pelo frio e pela umidade. Entre as enfermidades de verão estariam as "Dolores de costado, los Tabardillos, y calenturas ardientes (...)", além das doenças que teriam relação direta com o tempo seco como “(...) males de ojos, Dissenterias, Herpes, fuegos, o sarpullidos, comezón por todo el cuerpo, vahídos de cabeza, [etc.] males, que provienen delo sangre requemada". ${ }^{87}$ As doenças de inverno estariam, de acordo com o autor, estreitamente relacionadas com a umidade e as chuvas dessa estação e causariam, além dos problemas de cicatrização por causa da umidade, males como “(...) calenturas pútridas, y abundancía de flemas dela cabeza, y vientre, fluxiones, caída dela ternilla del estomago ensiforme, fluxos blancos del vientre, Hydropesías, y Hernías. Sobre todo opilaciones del Higado, y flaquezas del estomago, Pasmos, y otros afectos delos nervíos". ${ }^{88}$ Em relação às viroses e às epidemias, Sánchez Labrador diz que, de anos em anos, assolavam os indígenas, matando muitos deles no Paraguai, mas que, mesmo assim, não eram tão terríveis na Província Jesuítica do Paraguai quanto eram na Europa, pois, segundo ele, os índios seriam mais saudáveis do que os espanhóis e os forasteiros. A melhor forma de prevenir as epidemias e as viroses seria orientar os indígenas a evitarem o contágio, se afastando dos que estavam doentes, pois, uma vez enfermos, era muito difícil de tratá-los.

Ao final desse subcapítulo sobre as enfermidades mais comuns do Paraguai, Sánchez Labrador menciona os autores nos quais se baseou para fundamentar algumas das afirmações e recomendações feitas. Dentre eles, se destacam, em especial, os irmãos coadjutores Pedro Montenegro, autor de obras, em guarani e em espanhol, sobre farmácia, botânica, medicina e cirurgia; F. Agustin Farfan e Juan de Esteyneffer, autor da "Florilegio Medicinal". Entre os autores não jesuítas se encontram Jacobo Boncio ${ }^{89} \mathrm{e}$ Guilhermo Piso:90 "En el Discurso de esta ilustración dela Naturaleza del Paraguay se escriben muchos remedíos, que suministran los tres reynos Mineral, vegetativo, y sensitivo en estas dilatadissimas regiones, valéendonos delas noticias, que dan los Auctores referidos, y otros Libros". ${ }^{11}$ Nos próximos tópicos, compartilhamos a análise que fizemos dos demais tomos do Paraguay Natural Ilustrado, apresentando as virtudes medicinais elencadas pelo jesuíta para plantas, bezoares e insetos, assim como o diálogo que manteve com autores clássicos e contemporâneos e com outros jesuítas, atestando a circulação de informações que existia também entre os membros da Companhia de Jesus instalados em várias regiões dos Impérios ibéricos.

\section{Sobre a Parte Segunda}

51 O Tomo de Botânica, especificamente, está subdividido em sete livros, compostos por 76 capítulos, que abordam os seguintes tópicos: fisiologia, anatomia, histologia, reprodução vegetal; florestas, campos, pântanos, desertos; farmacologia, cultivo, etnobotânica, ao longo de 500 páginas. ${ }^{92}$ Sua análise nos revela que Sánchez Labrador se valeu tanto de suas próprias observações - a partir de expedições que realizava pela região platina - e de informações que obtinha com informantes indígenas, ${ }^{93}$ quanto de autores leigos clássicos e contemporâneos à obra, ${ }^{94}$ muitas delas, redigidas por outros jesuítas naturalistas, com os quais estabelecerá um interessante diálogo. Em uma das menções feitas ao ruibarbo, Sánchez Labrador deixa isto bastante evidente: "Dixome, que se las había hecho conocer un P. Missionero, inteligente de plantas, y aun que pronunció mal, como suelen los nombres estrangeros, pude percebir, que quería decir Ruibarbo". ${ }^{95}$ 

por outros homens de ciência do período, tanto na Europa, quanto na América, levavam em consideração os pressupostos da teoria humoralista hipocrático-galênica, ${ }^{96}$ segundo a qual a saúde era assegurada pelo equilíbrio entre os humores que compunham o corpo humano. Sendo assim, existia a concepção de que as enfermidades eram causadas justamente pelo excesso ou ausência de algum dos humores, o que levava a práticas que visavam à expulsão dos humores em excesso do corpo, através do sangue, das fezes, da urina, do vômito e de demais formas de excreção. A adoção desta teoria também fica evidente na proposição do emprego da medicina dos contrários, evidenciada em várias das passagens que destacamos na continuidade.

ao sistema de classificação das plantas proposto por Lineu (1707-1778), em 1753, ${ }^{97}$ constata-se que é apenas parcialmente empregado no Paraguay Natural, uma vez que Labrador, apesar de recorrer a muitos elementos propostos pelo botânico, opta, no entanto, pelo agrupamento por formas biológicas, ${ }^{98}$ isto é, por biótipos. ${ }^{99}$ Acredita-se que a não adoção da nomenclatura de Lineu ${ }^{100}$ por Sánchez Labrador possa ser atribuída tanto ao fato de que a metodologia e a classificação por ele propostas ainda não se encontravam largamente difundidas e aceitas pelos naturalistas e botânicos, ${ }^{101}$ quanto aos insuficientes dados morfológicos que o jesuíta possuía sobre certas espécies e famílias sul-americanas para poder enquadrá-las nos tipos de Lineu.

No Paraguay Natural, cada planta descrita por Labrador está precedida por descrições morfológicas e ecológicas, seguidas por informações sobre sua utilidade, além do seu método de obtenção e cultivo. A obra contempla critérios de classificação próprios da botânica, tais como taxonomia, morfologia, anatomia e, também, aspectos etnobotânicos e relativos aos tratos culturais, os quais, segundo o padre jesuíta, eram, até aquele momento, tratados isoladamente por outros cientistas. Isto fica evidente na afirmação que Sánchez Labrador faz na abertura do Tomo de Botânica:

(...) Muchos auctores restringen la Botanica à solo el conocimiento de las Classes, Generos, y Especies de las Plantas; à su exterior forma, y la descripción de todas sus partes. Estoy de acuerdo, que su objeto comprehenda todo el Reyno de los vegetables, en todos sus estados, en todos sus usos, y en todos sus respectos. ${ }^{102}$

Nesta mesma introdução, ele acrescenta que pretendia fazer uma descrição completa e minuciosa sobre as plantas das regiões da América platina, especialmente da Província Jesuítica do Paraguai, o que fica evidenciado nesta passagem:

(...) si se mira bien, verá en lector, que no se trata aquí de dar una noticia ayuna y enjuta de las plantas del Paraguay, sino, en cuanto se ha podido, se trató de formar una Botánica, de las que produce este país, considerado hasta ahora con casi ningún cuidado y empeño. ${ }^{103}$

Neste tomo, ficam também evidentes os conhecimentos químicos de Sánchez Labrador, especialmente, na seção em que trata das cores das plantas e dos procedimentos que deveriam ser adotados, ainda no plantio, para a obtenção de determinadas colorações. $O$ autor fala, com bastante propriedade, das influências dos ácidos e dos alcalinos nas cores das flores, informando que os ácidos levariam a tons avermelhados, enquanto que os alcalinos causariam tons mais puxados para o verde. Suas explicações sobre as aparências das plantas e sobre a composição dos solos, sobre as diferenças entre alcalinos e ácidos, bem como de alcalinos voláteis e ácidos voláteis, e sobre como esses elementos influenciam na coloração das plantas, são bastante complexas e demonstram um conhecimento significativo, decorrente, sem dúvida, do contato com obras de referência sobre a temática. Além das descrições morfológicas e ecológicas e das informações sobre

Corpus, Vol 6, No 2 | 2016 
sua utilidade, além do seu método de obtenção e cultivo, o jesuíta apresenta, ainda, uma série de advertências, objetivando o êxito na busca e no emprego de determinado vegetal.

Merecem, sem dúvida, destaque as mais de cem descrições que o missionário jesuíta fez "de las árboles del Paraguay", que são organizadas seguindo um critério fisionômico e utilitarista, como se pode constatar nas árvores balsâmicas, dentre as quais se destaca o cupay (Copaifera sp.), nome vernáculo atribuído a diversas espécies nativas, produtoras de óleos essenciais terapêuticos, que foram empregadas nas reduções jesuíticas na preparação de diversos bálsamos, úteis no tratamento tanto em lesões externas, quanto da varíola. De acordo com Labrador, desta planta extraía-se um poderoso bálsamo, conhecido como o azeite de Cupay, bálsamo de Copayba ou azeite de Palo. Dentre suas virtudes medicinais estariam as de confortar o estômago (tomando-se 3 a 4 gotas pela manhã), ser diurético (limpar os rins e bexiga), curar as dificuldades relacionadas à má respiração, induzir o parto, quando aplicado na vulva, diminuir as dores dos nascidos que apresentam humores frios e úmidos, a paralisia, pois o chá é posto na origem dos nervos, na espinha (humores frios), diminuir as dores de gota, ajudar nas dores no ciático, fortificar o cérebro e afastar o frio da febre. Além dessas aplicações, o bálsamo da copaíba seria muito conhecido também por seus efeitos na cicatrização de feridas de todos os tipos (menos as produzidas por queimaduras). Serviria, ainda, para conter os fluxos de sangue, decorrentes do rompimento de alguma veia ou vaso sanguíneo, podendo ser aplicado em casos de gangrenas, gonorreias ou demais enfermidades que causassem perda de sangue, porque "Provoca la orina, apaga su ardor, y limpia las cosas ensangrentadas, sucias, y podridas del vientre, que la detienen". ${ }^{104}$

Em relação ao pau-brasil (Ybirapicta em guarani), Sánchez Labrador reconhece sua larga utilização na extração de tintura, destacando a existência de dois tipos de Ybirapicta, a Ybirapicta guaçu e a Ybirapicta miri. Quanto às virtudes medicinais do pau-brasil, o padre jesuíta ressalta que estas árvores possuem muito óleo e pouco sal essencial, apresentando qualidade adstringente, sendo, por isso, eficientes para fortificar o estômago e diminuir as febres altas, para curar graves inflamações nos olhos e combater a icterícia. ${ }^{105}$

Um aspecto que chama a atenção ao longo deste tomo e de seus capítulos, são as advertências quanto ao uso de determinadas plantas e as inúmeras recomendações feitas por Labrador, como por exemplo, em relação aos cuidados que se deveria ter nas expedições de reconhecimento e coleta e, ainda, em relação ao consumo de certos alimentos, como se pode constatar nesta passagem: "Los índios se valen de uno médio para no perder el tino (...) cortan ramas, y gajos de los arboles, y plantas de media altura; aquellas suelgan en alguno ramo del camiño, y estas las dexan pendientes". ${ }^{106} \mathrm{E}$, ainda, que deveria se tomar cuidado na coleta dos frutos de algumas plantas, pois alguns deles podiam apresentar toxicidade: "En este conflicto, sirven de exploradores al gusto Insetos, ò nobles Aves. Las frutas, que se ve comen tales animalitos, se pueden julgar de buenas qualidades, y comerse sin miedo". ${ }^{107}$ Sánchez Labrador, contudo, não descuida de legitimar suas observações a partir do conhecimento já consagrado de alguns botânicos: "Me alegre al leer algunas de estas advertencias en la obra del insigne Botanico, P. Savastaní, el mismo elegante Poeta escribe que de este mismo indício se valieron los europeus (...), tenian por salutables aquellos frutos que las aves picaban". ${ }^{108}$

Aspecto que merece destaque são as inúmeras evidências da circulação de "libros de medicina" e do diálogo que Sánchez Labrador mantinha com outros membros da Companhia de Jesus, como nesta passagem em que descreve a "Caaboroy": 
(...) asi llaman a una planta, que abunda en el Paraguay Proprio, a la qual nombram los españoles, Albahaca del campo, o silvestre. Parecese en todo a la Albahaca hortense, a la qual los indios Guaranis dan el mismo nombre. La del campo, quando fresca despide olor muy suave de clavo de especeria. El Hermano Pedro Montenegro , Jesuita, y insigne Botanico, la tomaba a la manera de The, y decía, que confortaba bellamente el estomago. ${ }^{109}$

Ou, então, nesta em que, ao tratar de uma "especie de the", menciona que:

Las hojas de este arbolito son muy fragrantes; y en Chile, y en el Paraguay se sirven de ellas, como de las del The, con los mismos, o mejores efectos. Por una especie de verdadedo The califico a esta planta el P. Thomas Falconer, ingles, Jesuita en la Provincia del Paraguay, sugeto muy inteligente de la Botanica, y Medicina. La Autoridad sola de este insigne Missionero puso al Culen en mas alto grado de estimación de el que antes tenia. Como científico manifiesto, que poseía mucha sal esencial, y oleo medio exaltado. ${ }^{110}$

62 A circulação de informações sobre saberes e práticas curativas entre reduções da Companhia na região abarcada pela Província Jesuítica do Paraguai pode ser constatada na menção que Sánchez Labrador faz à uma "Reducción de Neophytos del Chaco [onde] se atajó una epidemia con el remedio dicho del Tabaco, como me lo refirió el P. Luís Olcina, que actualmente se hallaba en ella, y otros missioneros". ${ }^{111}$ Mas o diálogo entre jesuítas não se circunscreveu ao período em que padres e irmãos atuaram no território americano, como se depreende desta passagem, na qual Labrador, já instalado em Ravena, refere ter recebido notícias do:

(...) P. Diego Moreno, de la Provincia de Chile, que a la sazon se hallaba en Ravenna, sugeto grave, y de gran discernimiento. Dixome, que en Massa Lombarela, donde el residía, lugar cercano a la ciudad de Immola, había un Cavallero Conde de la primera nobleza, muy curioso, y que se deleitaba en Botanica, y Jardineria, el qual en su bello Jardin tenía también el Payco, al qual nombraba The, y como tal le usaba. Suplique al Padre, que a su regreso, se informase con puntualidad de este particular, y que me escribiera lo que averiguaría. Hizolo así, y respondío lo que ya voi a escribir con sus formales palabras. ${ }^{112}$

Esta intensa circulação de informações, em especial, sobre Botânica, não somente entre membros da Companhia de Jesus, mas também a confirmação ou a refutação de estudos clássicos e publicados no Setecentos podem ser também constatadas no próximo tópico, no qual enfocamos as virtudes medicinais das pedras bezoares, apresentadas, especialmente, no Livro III do Tomo II e no Livro I do Tomo III.

\section{Sobre a Parte Terceira}

O primeiro Livro da Terceira Parte da obra, intitulado Animais Quadrúpedos, conta com um capítulo intitulado De las Piedras Bezares, que trata, especificamente, das origens dos bezoares, das espécies de bezoares, de suas virtudes e falsificações. Vale ressaltar que, ao longo do quinto capítulo do terceiro Livro da Segunda Parte do Paraguay Natural Ilustrado, o jesuíta também faz referências às virtudes medicinais das pedras bezoares e a sua utilização tanto por europeus e orientais, quanto pelos indígenas da Província Jesuítica do Paraguai. É sobre as descrições das virtudes terapêuticas das pedras bezoares e sua indicação no tratamento de certas enfermidades que nos deteremos na

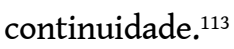

Desde a Antiguidade, as pedras bezoares - "concreções formadas por camadas de lâminas calcárias sobrepostas" -, especialmente as que se formavam nos estômagos de veados e 
cabras, foram empregadas no tratamento de uma série de enfermidades, creditando-se a elas "o poder de opor-se aos envenenamentos". ${ }^{114}$ A eficácia destas pedras contra intoxicação logo se espalhou pela Ásia e chegou à Europa, onde seu largo uso fez com que as mezinhas utilizadas contra venenos fossem chamadas de "bezedáricas" pelos boticários, médicos e naturalistas do século XVI. ${ }^{115} \mathrm{~A}$ origem etimológica da palavra deriva, justamente, da crença em sua eficácia curativa. Segundo o historiador jesuíta Pedro Grenón, “(...) Bezar etimológicamente proviene del nombre persa bad que significa "viento" y zahr "veneno", los cuales dos nombres en su composición dan la idea de lo que sopla o disipa el veneno o sea el contraveneno o antídoto (...)" ${ }^{116}$

Estas concreções eram definidas a partir de sua localização geográfica, daí serem denominadas de ocidentais ou orientais. Sobre a sua descoberta e uso medicinal, Sánchez Labrador afirma que,

Alos Arabes, pues, y a los Modernos se debe el descubrimiento del Bezar oriental, y de sus virtudes; como el del Bezar ocidental de las vicuñas, [etc.] a los indios del Peru, yal diligente examen delos españoles, curiosos investigadores dela naturaleza delos Países americanos. ${ }^{117}$

Portanto, a pedra bezoar americana, segundo o jesuíta, podia se formar nos estômagos dos guanacos, como evidenciado na situação relatada no Paraguay Natural, na qual um índio, por ter mostrado suas virtudes medicinais aos espanhóis, teve sua vida e a de seus companheiros poupadas, ${ }^{118}$ ou, então, nos de animais como as vicunhas, "por la calidad de los pastos, de que estos animales se alimentan. Se aumenta sobreponiéndose costras a costras. Por esto quanto mas vieja es la vicuña, tanto mayor es la Piedra Bezoar que se le encuentra". ${ }^{119}$ No entanto, o jesuíta alerta para o fato de que nem todos os guanacos ou vicunhas, mesmo os mais velhos, possuíam pedras bezoares em seu interior. Pois, a matéria das ervas ingeridas poderia ser excretada, ao invés de ser retida, ou mesmo as pedras poderiam ser dissolvidas no estômago do animal.

De acordo com Sánchez Labrador, o padre José Cardiel ${ }^{120}$ também havia constatado que

En las tierras de los Patagones se crían guanacos de cuyas pieles hacen sus mantas. Con estas mantienen trato con las demás naciones. También venden las piedras bezares, que sacan de dichos animales, entre las cuales algunas son grandes y de muchas onza de pesos. ${ }^{121}$

69 Informações sobre a prática de extração destas pedras, sua utilização terapêutica e posterior comercialização, podem ser também encontradas na obra Ensayo sobre la História Natural del Gran Chaco, escrita pelo jesuíta José Jolís, durante seu exílio em Faenza, na Itália. Nela, o missionário refere o uso de "animales en la cura de diversos trastorno desde las famosas piedras bezoares hasta los corazones y excrementos de aves". ${ }^{122}$ Também o padre Falkner ${ }^{123}$ refere a formação de pedras bezoares nos estômagos de antas e sua utilização pelos indígenas da Patagônia:

Hay tambien mucha caza menor, de que viven principalmiente los indios. Encuentrase igualmente gran cantidad de bezoar, no solo en los estômagos de los guanacos, vicuñas, sino tambien en los del anta, aunque el de este es mas ordinaria y comun. Cuando se administra en cantidad considerable, promueve muy bien un diaphoresis. Experimente que daba grande alivio en los dolores de estómago, desmayos. Su dosis consiste en una dracma, ó dus escrupulos, tomado en cualquiera cosa; bien que se podria administrar mayor cantidad con toda seguridad. En muchos casos vale mas que el polvo de oculi, cancron, ó polvos de testaceos, y otras sustancias minerales. He tenido algunas de estas piedras que pesaban 18 onzas. ${ }^{124}$ em detrimento de outras -, Sánchez Labrador recorre ao relato do padre jesuíta Alonso de 
Ovalle, ${ }^{125}$ "que alega (...) que en tales sítios corriendo los Huanacos, heridos dela repetidas picaduras de las Bivoras, buscan al punto húerbas salutíferas". ${ }^{126} \mathrm{E}$, também, ao observado pelo padre Pedro Lozano, ${ }^{127}$ que, em sua obra Historia de la Conquista del Paraguay, Río de la Plata y Tucumán, ${ }^{128}$ afirma:

La materia de que forman dichas piedras son yerbas de gran virtud, que por instinto natural buscan (los animales) o para curarse, o para preservarse de sus ataques, o para impedir que llegue al corazón la ponzoña de víboras o arañas venenosas que pican, y es cosa experimentada que en los países donde abundan más los animales ponzoñosos, es también mayor la copia de piedras bezoares, como se ve en los guanacos en Chile, reyno muy limpio en sabandijas, se encuentran muy raras, pero en esta parte de la Cordillera, como es mucho mayor el número de vivientes nocivos, se hallan los bezares con mucha abundancia. ${ }^{129}$

Na percepção de Ovalle e Lozano, a alta incidência de víboras na região que abrangia a então Província Jesuítica do Paraguai - apresentado como o País de las Bivoras e de muitas outras espécies venenosas - favorecia a formação de bezoares nos estômagos de animais, inclusive, no Cuy, um mamífero roedor. Já as regiões da Província do Chile ${ }^{130} \mathrm{e}$, especialmente, as terras próximas ao Estreito de Magalhães, que possuíam clima excessivamente frio e pouco propício às víboras, contariam com uma quase inexistente produção de pedras bezoares, que se formariam, preferencialmente, onde "abundan semejantes Reptiles nocivos". ${ }^{131}$ No Paraguay Natural, Sánchez Labrador ressalta que as pedras bezoares encontradas em cabras ou cervos e, também, nos estômagos de bois, águias, caranguejos, cuis e porcos-espinho, ${ }^{132}$ eram medicinais, porque "formadas de algunos jugos de las hierbas saludables, que estos animales pacen, y ruminan". ${ }^{133}$

O uso das pedras bezoares, ainda que muito difundido, suscitou diversos questionamentos sobre a sua eficácia, sendo que o seu elevado valor de mercado e a sua origem geográfica foram as variáveis mais destacadas deste debate. Diferentemente de outros estudiosos dos séculos XVII e XVIII, como Esteban Francisco Geoffroy, ${ }^{134}$ Nicolás Lemery, Guillermo Piso e George Marcgrav, ${ }^{135}$ Sánchez Labrador não acreditava na inferioridade do bezoar ocidental, o americano, ressaltando, inclusive, sua superioridade em relação ao oriental. Geoffroy rechaçava e reprovava a utilização dessas pedras, observando que, caso fosse necessário usá-las, a quantidade deveria ser muito superior a dos bezoares orientais, vistos como mais eficazes. Já Piso e Marcgrave, apesar de afirmarem que os cervos do Brasil produziam pedras bezoares inferiores às orientais, irão ressaltar sua bem sucedida utilização contra venenos pelos indígenas. Sánchez Labrador, por sua vez, afirma que as pedras bezoares americanas eram melhores e preferíveis às orientais por não serem falsificadas:

Ve aquí descubierta una regla, que hace apreciabilisimas las Piedras Bezares del Paraguay, y preferibles a las orientales, o que como tales se juzgan, yse venden. En el Paraguay las logramos sin adulteraciones, ni imposturas: todas son Naturales, y genuinas. En España un H. Jesuita, muy inteligente en la Pharmacia, que exercía en el Colegio de la Insigne Universidad de la Salamanca, habido hecho todas las pruebas en orden a experimentar las virtudes de los Bezoares del Paraguay, los depuso a los orientales, y pidió con instancias, que le remitiesen otras de estas Piedras en cantidad, como se hizo. Por otra parte en el Paraguay con grande, y casi quotidiano uso, se experimentan sus buenos efectos; conque si en Europa se tienen por de poco valor, acaso sera, porque las tingen, y contra hacen, bautizándolas con el nombre de Bezar occidental. ${ }^{136}$ na Europa, a partir, da mistura de pós, resinas e outros materiais viscosos, acabaram 
prejudicando, até mesmo, o reconhecimento das propriedades terapêuticas das pedras bezoares, especialmente, das americanas. O seu alto preço, além de estimular a falsificação, impactava também no correto uso das pedras bezoares. Segundo Sánchez Labrador:

Hay también muchas circunstancias, que contribuyen a poner en duda las virtudes de la Piedra Bezar, y a hazerlas inciertas, y de no facil averiguación. Tales son la incertidumbre de no lograr una Piedra Bezar genuina, por falsificarlas no solamente en el oriente los indios, sino también muchos en Europa, poseidos de la codicia, y anxiosos de conseguir el alto precio, a que se venden. Añadase, que lo caro, a que los dan Boticarios, es causa de que no se recete en muchíssimos casos, o por lo menos, no en la cantidad suficiente, no en repetidas dosis, como de hecho seria necesario, para poder determinar, si las virtudes, que seles atribuyen a los Bezares, son reales, o solamente imaginarias. ${ }^{137}$

Também no capítulo V, do Livro Três da Segunda Parte, intitulado Los Arboles en Particular, Sánchez Labrador faz referência às pedras bezoares. Segundo o jesuíta, Esteban Geoffroy atribuía a origem das pedras bezoares às sementes das plantas Acácias ou Yobopeys, as quais, após serem ingeridas por certos animais, estariam sujeitas à ação dos ácidos existentes em seus estômagos, propiciando a formação das pedras bezoares. Para o padre jesuíta, esta opinião não deveria ser completamente desconsiderada, contudo, suas observações haviam demonstrado que nem todas as regiões possuíam animais bezoárdicos e nem sempre eles eram encontrados onde existiam Acácias ou Ybopeys. ${ }^{138}$

Ao longo de vários capítulos do Paraguay Natural Ilustrado, o jesuíta destaca que tanto o bezoar ocidental, quanto o bezoar oriental possuíam suas virtudes relacionadas com a quantidade de sal volátil alcalino e sulfúreo que continham, sendo também bastante oleosos e contribuindo para a limpeza dos ácidos do corpo. Por possuírem estas propriedades, os bezoares seriam diaforéticos, provocariam o suor, sendo bons contra os venenos, dissipando as vertigens da cabeça e as palpitações do coração, e matando as lombrigas. Sánchez Labrador recomenda que as pedras fossem reduzidas a pó e que as doses deveriam ser de quatro até seis grãos tomados pela boca ou, então, a pedra embebida em algo que o jesuíta denominou de conveniente. Outra orientação dada por ele é a de que as pedras bezoares deveriam ser escolhidas por sua grandeza moderada e por sua cor aproximada, sendo que as não falsificadas deveriam soltar uma tintura amarelada ou esverdeada, não se desfazendo ao serem colocadas na água. Deste modo, Sánchez Labrador recomendava a utilização das pedras verdadeiras, discordando, assim, de outros autores que estabeleceram distintas eficácias para as diferentes formas das concreções:

Los inteligentes tienen por mejores, y mas estimables aquellas Piedras Bezares, cuyo color es algo verdoso, y su figura redonda. Inferiores a estas juzgan las ovales, o de figura de huevo; y las ínfimas las cylindricas. Pero a la verdad la figura conduce muy poco, o por mejor decir nada a la virtud de los Bezares, con tal que la materia, de que se forman, sea la parte gomosa de las hierbas. Fuera de esto, no todas las capas, que componen un Bezar, tienen el mismo color, y groseza. ${ }^{139}$

Vale ressaltar que o jesuíta compreende as virtudes medicinais atribuídas às pedras bezoares a partir de pressupostos da teoria humoralista hipocrático-galênica, segundo a qual a saúde era assegurada pelo equilíbrio entre os humores que compunham o corpo humano. A associação das virtudes terapêuticas tanto das pedras bezoares, quanto de outros medicamentos com a teoria hipocrático-galênica não foi feita unicamente por Sánchez Labrador, sendo comum entre os estudiosos do século XVIII e dos séculos anteriores. No caso específico da pedra bezoar, o autor destaca que ela “(...) promueve la 
transpiración, o sudor, resiste a la malignidad de los venenos (...)", ${ }^{140}$ evidenciando sua concepção de que ela apresentava propriedades terapêuticas porque promovia, através da transpiração do corpo, a eliminação dos humores que estavam causando a enfermidade. ${ }^{141}$ Assim, para Sánchez Labrador, a pele era o órgão responsável tanto pelo tato, quanto pela transpiração sensível, a ponto de o autor se questionar se "A vista de esta noticia causara admiración, que esta transpiración, o impedida, o minorada, cause la mayor parte de las enfermedades?". ${ }^{142}$

De acordo com a historiadora argentina Maria Silvia Di Liscia, ${ }^{143}$ as pedras bezoares eram tidas como essenciais nas boticas europeias e americanas, sendo também referidas nas farmacopeias, nos compêndios e receituários da Companhia de Jesus e nas listas de mercadorias solicitadas aos Procuradores da ordem que se dirigiam à Europa.

Evidenciando a recomendação da utilização de pedras bezoares pelos jesuítas dedicados às artes de curar destacamos duas receitas extraídas da já citada Materia Medica Misionera, escrita pelo irmão jesuíta Pedro Montenegro (1710), que atuou como boticário junto ao Colégio de Córdoba e, posteriormente, como missionário em várias reduções. Numa delas, a pedra é utilizada contra a varíola, juntamente com quatro folhas de calamita menor (planta equisetínea) e duas onças de açúcar, o que provocava suores nos pacientes, razão pela qual o boticário recomendava que estes se resguardassem do vento. Em outra receita, Montenegro faz menção ao seu uso combinado com folhas da sextula maior: "E se lhe colocam umas duas folhas de borragem [borracha-chimarrona] ou de pedra bezoar, por ser mais sudorífica, atenua as dores internas, assim do ventrículo como do fígado". ${ }^{144}$

O inventário do Colégio de Córdoba, realizado logo após o decreto de expulsão da Companhia de Jesus, nos anos de 1771 e 1772, confirma que as pedras bezoares integravam "los bienes medicinales" das boticas deste colégio jesuítico da Província Jesuítica do Paraguai. ${ }^{145}$ As pedras aparecem relacionadas na categoria Preparaciones y Polvos, ao lado de chifres de cervo, dentes de javali, corais e olhos de caranguejo, pós de víbora e esperma de baleia, e, ainda, na categoria dos Polvos cordiales, na qual é feita, inclusive, uma distinção entre a pedra bezoar ocidental e a americana, ${ }^{146}$ que aparecem, mais uma vez, relacionadas entre outros itens, tais como corais, madrepérola e olhos de caranguejo. ${ }^{147}$ Também os insetos atraíram a atenção do padre jesuíta Sánchez Labrador e é sobre suas virtudes medicinais que tratamos na continuidade.

\section{Sobre a Parte Quarta}

O Quarto Tomo da obra Paraguay Natural conta com um capítulo dedicado às virtudes medicinais de alguns insetos. De acordo com Sánchez Labrador, "Los Insectos no tienen uso tan general en orden a la salud, como el resto de los otros animales" pois, "Los Medicos no emplearon mucho tiempo en indagar las virtudes especificas de los primeros, satisfechos con lo que conocian en los segundos". ${ }^{148}$ No entanto, segundo o jesuíta, estes animais invertebrados, reduzidos a pó ou ingeridos em infusões, agiam na cura de enfermidades internas e na recuperação de fraturas ósseas, visto que apresentavam expressivas virtudes terapêuticas:

Pueden se alegar varias razones en comprobación de la virtud, que se halla en estos pequeños vivientes, ${ }^{3}$. que la sal, que tienen, es mas penetrante, y volátil, que la de otros animales. Es cierto a muchos Insectos abundan de sal volátil, la qual se extrahe facilmente por medio de la chymica. II ${ }^{a}$. que los Insectos contienen una 
especie de Balsamo natural, capaz de producir buenos efectos. III ${ }^{\text {a }}$ que tienen un Azufre mas eficaz, que lo común. ${ }^{149}$

81 encontram os escorpiões, "Yapeuzu" em guarani, os quais, segundo Sánchez Labrador, se amassados e colocados sobre a própria picada de seu ferrão, conseguiriam deter o progresso do veneno no corpo da vítima, levando à cura. Para confirmar esta indicação, o padre jesuíta se vale da opinião de outro jesuíta, o padre Athanasius Kircher, ${ }^{150}$ que afirmava que os escorpiões atraíam o seu próprio veneno através de uma virtude magnética. Ainda contra o veneno destes insetos, seria bastante eficiente o emprego de "Aceyte de Alacranes" - ou azeite de escorpiões -, produzido através da infusão de escorpiões em azeite de amêndoas, que deveria ser aplicado sobre a área picada. ${ }^{151}$ De acordo com o jesuíta, os indígenas, quando picados por escorpiões, ingeriam estes animais amassados misturados à bebida fermentada, enquanto outros preferiam colocar o azeite dentro da ferida. O escorpião, segundo ele, possuía também virtudes diuréticas, auxiliando no tratamento de pedras nos rins e na bexiga, devendo, nestes casos, ser queimado vivo e suas cinzas consumidas posteriormente. Para contornar este mesmo problema, era indicado o azeite de escorpiões, devendo-se untar a região da bexiga e dos rins, para, assim, amenizar as dores e ajudar o enfermo a expelir as pedras. 0 azeite podia, ainda, aliviar dores de ouvido, quando pingado nas orelhas.

m os grilos possuíam uma grande quantidade de sal volátil e de óleo, sendo, por isso, também eficientes como diuréticos. Estes insetos deveriam ser colocados em um vaso de terra tapado, que deveria ser aquecido sob fogo baixo, para, logo após, serem reduzidos a um pó, que deveria ser dado ao paciente - na quantidade de doze grãos ou mais -, acompanhado de água de salsa. Outra forma de utilizá-los como medicamento, sem que fosse preciso tostá-los, previa que dois ou três desses insetos, após terem removidas suas asas, pernas e cabeças, fossem colocados em água de salsa ou alecrim. Estes insetos deveriam ser deixados em maceração nessa água até que ela se tornasse um licor praticamente branco como leite, que deveria ser coado em um pano e dado de beber para o enfermo. Os grilos também teriam uso externo, já que, após serem amassados e aplicados nos olhos, ajudavam a clarear a visão, sendo também eficientes na cura de parótides e de outros tumores do mesmo gênero.

Sánchez Labrador registrou duas formas de preparo de grilos por indígenas. Uma delas consistia em cozinhar alguns grilos, retirar suas tripas e moer o restante de seus corpos até tornarem-se pó, ao qual era acrescentado um "licor conveniente" dado aos doentes que padeciam de problemas dos rins ou bexiga, com grandes resultados. A outra recomendava que, nos casos de urina contida, o doente recebesse o preparado resultante da seguinte receita: dois grilos deveriam ser tostados em uma caçarola de barro, moídos e misturados em um pouco de vinho, água bem cozida ou de chicha de milho. Mas se o paciente sofresse de incontinência urinária, deveria receber um só grilo, amassado e não tostado, misturado com um pouco de água morna. Eles poderiam ser também colocados em um palito e tostados no fogo, como nesta indicação: "y ya tostados muelelos en un poco de vino caliente: este vino mezclado con los Polvos de Quiyus, darás ao Indio, o India, que padeciere la retención de orina, y esta poco a poco fluirá". ${ }^{152}$

Assim como os grilos, os piolhos continham sal volátil e óleo, sendo indicados nos casos de icterícia e febres, recomendando-se que fossem engolidos de cinco a seis deles, no princípio do paroxismo. Concordando com o proposto pelo químico francês Nicolás Lemery, Labrador ressalta que o paciente que demonstrasse aversão e apresentasse 
náuseas ao engolir os piolhos, estaria, na verdade, expelindo a febre e não o remédio em si. Para curar a icterícia, as orientações eram as seguintes: alguns destes insetos deveriam ser consumidos pela manhã - em jejum - em um ovo passado pela água, repetindo-se três vezes este procedimento por três dias consecutivos, interrompendo-se por alguns dias para, depois, repetir o procedimento. O uso externo dos piolhos, segundo Sánchez Labrador, era frequente em crianças que sofriam de retenção urinária, recomendando-se que o inseto fosse colocado vivo sobre alguma parte do corpo do enfermo.

Em relação a este último Livro da quarta Parte do Paraguay Natural Ilustrado chamou-nos a atenção o fato de que praticamente todos os insetos citados por Sánchez Labrador apresentam propriedades diuréticas, auxiliando, ainda, no tratamento de pedras nos rins e na bexiga. Esta constatação, que precisa ser estudada mais detidamente, parece apontar para a alta incidência destas enfermidades entre os grupos indígenas contatados ou observados pelo missionário jesuíta, e que podem estar relacionadas com mudanças nos hábitos alimentares, mais especificamente, do consumo de sal ou de açúcar, após a intensificação do contato com os europeus. ${ }^{153}$

Percebe-se, ainda, que Sánchez Labrador fundamenta o emprego terapêutico destes insetos a partir de pressupostos da teoria humoralista, na medida em que levam o enfermo a expelir os excessos dos humores em desequilíbrio. A apropriação da teoria hipocrático-galênica pode ser constatada em várias passagens, como na referência que o jesuíta faz à náusea provocada pela ingestão de piolhos, que consistiria, segundo ele, justamente, na maneira de o corpo eliminar a febre.

87 Ao longo das mais de trezentos e setenta páginas deste livro, Sánchez Labrador evidencia não apenas a apropriação dos saberes e das práticas curativas nativas, mas também a legitimação ou a refutação dos pressupostos de vários autores europeus, ao quais ele recorre para fundamentar suas afirmações e descrições das indicações terapêuticas e modos de preparo dos insetos. Dentre os referidos pelo padre jesuíta, destacam-se Robert James (1703-1773), Nicolás Lemery (1645-1715), Esteban Geoffroy (1672-1731), JacquesCristophe Valmont de Bomare ${ }^{154}$ (1731-1807), Marcial ${ }^{155}$ (38/40 d.C.-?), Dioscórides ${ }^{156}$ (40 d.C.-90 d.C.), Padre Athanasius Kircher SJ. (1601-1680), Martin Lister ${ }^{157}$ (1638-1712), Johann Schröder ${ }^{158}$ (1600-1664) e Cláudio Galeno ${ }^{159}$ (129-199/217 d.C.).

88 A referência a Galeno pode ser encontrada na passagem em que refere a utilização de "agua destilada de Moscas (...) contra los males de los ojos; para servirse de ella la mezclan con una yema de huebo, y forman emplasto. Galeno aprueba este remedio". ${ }^{160}$ Ao tratar das propriedades terapêuticas do mel das abelhas, Labrador deixa bastante evidente as leituras que realizou e os autores nos quais se baseava: "Otras virtudes excelentes dela Miel podrán leerse en las Pharmacopeas Matritense, de Lemery, Palacios, James". ${ }^{161}$ Mas, ao referir-se à cera de abelha, o jesuíta deixa evidente sua discordância em relação ao já afirmado por Lemery que:

(...) juzga, que no hay mas cera virgen, que la que en las colmenas se llama propolis, y en Guarani Eybora; que es una especie de Matice dorado, o rubicundo, el qual contiene mucho oleo, y poca sal volátil acida. Es error este de Lemery, y solo impropriamente puede la Propolis llamarse Cera Virgen..$^{162}$

Em outra passagem, que trata, especificamente, das sanguessugas, o jesuíta irá ressaltar as acertadas recomendações feitas pelo químico francês:

Para aplicar las sanguijuelas son necessarias algunas precauciones, que podran verse en el Diccionario de Drogas Simples de Lemery. Este Auctor enseña, que si por casualidad, bebiendo agua, se trago alguna sanguijuela, luego o se beba agua salada 
en abundancia, porque con ella desiste este insecto de atormentar; y que después se purgue con Mercurio dulce, u otra composición Mercurial. ${ }^{163}$

Para abordar as propriedades terapêuticas de aranhas e de suas teias, Sánchez Labrador recorre aos trabalhos tanto de Martin Lister, quanto de Robert James, como se pode constatar nas passagens que destacamos. Em relação ao primeiro autor, o jesuíta afirma que em seu "/Tractat. De Araneís/ [Lister] las atribuye muchas facultades medicinales; pero se desean buenas pruebas, fundadas en experiencias". ${ }^{165} \mathrm{Na}$ referência que faz ao segundo, Labrador não apenas recorre a James para legitimar as virtudes e o mais adequado procedimento terapêutico, como para reforçar sua eficácia a partir de experiências bem sucedidas e de registros que a comprovam:

James escribe que se ha de tomar una vez una hora antes que venga el paroxismo; y otra vez quando ya esta próximo a venir. Dice, que le informaron, que los indianos en la Carolina Septentrional, tiene grande confianza en este remedio para el dicho mal, a que están muy expuestos. Añade, que un amigo suyo, que había estado muchos anos en aquellas tierras, le asseguro, que el mismo había sanado de aquel mal con la tela de Araña. Concluye James, y de hecho, la experiencia misma confirma la eficacia de este remedio para sanar las calenturas, que vienen con frío. 166

Este recurso narrativo de legitimação pode ser também observado em outras duas situações, nas quais, ao referir-se à cochonilla, o jesuíta respalda suas descrições em autores como Geoffroy, Schröder e Lemery:

Geoffroy dice, que se usa la cochonilla para todos aquellos fines, a los quales sirve el Chermes. (...) En los Pasmos delas Quixadas, en que estas se aprietan de modo que se cierra fuertemente la boca, son excelentissimo, y prompto remedio, cogese un pedacito de Grana, (que es la substancia de los Gusanos) como una Almendra; desliese en vino; abrese la boca del enfermo con algún palito, y se le hecha en ella la dicha infusión algo tíbia con una cuchara: luego sele desetan los nervios, y habla. Practique este remedio en una ocasión, que llamado a confessar una enferma en la ciudad de Buenos Ayres, la encontré con el referido Pasmo. Pudo por este medio confessarse a satisfacción. De otras virtudes dela Grana, vease Schroder en el Libr. citad. Geoffroy. Lemery. ${ }^{167}$

Schröder será novamente mencionado na descrição que Labrador faz das virtudes medicinais dos besouros: "Dice Schroder, que el aceyte hecho de la infusión de estos insectos, puesto en el oído, o instilado en la oreja, quita los dolores de los oídos, yla sordera". ${ }^{168}$ Mas esta não será a única forma de preparo dos "escarabajos", uma vez que Labrador irá destacar também "El modo mejor de hacerlos polvo, segun Hartmannes, es (...) meter algunos escarabajos en un vaso de tierra; taparle bien, y ponerle al sol a secar; después moerlos". ${ }^{169}$

Referindo-se à utilização terapêutica de piolhos, Labrador descreve e, ao mesmo tempo, desacredita uma das práticas adotadas, afirmando que

En quanto a el uso externo, sirven para los Ninõs [os indios], que padecen supressión de orina: suelen poner vivo un Piojo en el Cañoncito, que con la titilación se ensancha, y da lugar a que la orina salga. Schroder no aprueba esto. ${ }^{170}$ 
em uma perspectiva humoralista, a retomada do equilíbrio:

Densele al enfermo al principio del paroxismo cinco, o seis, y que los trague, o mas o menos, según se juzgare conveniente. Nota muy bien Lemery, que por ventura al asco, y nausea, que siente el paciente al tomarlos, conduce para expeler la calentura mas, que el mismo remedio. ${ }^{171}$ fica, portanto, evidente a "necessidade de um comentário autorizado da parte de quem é suficientemente "sábio" ou "profundo". ${ }^{172}$ Entretanto, o que chama a atenção, especificamente, neste livro do Paraguay Natural, não são as recorrentes remissões e evocações aos conhecimentos de autoridades reconhecidas, mas as menções que Labrador faz às contribuições de outros sujeitos, no caso, os indígenas, a quem denomina de "inteligentes" e "sábios" em algumas situações. Em uma das descrições sobre a utilização terapêutica de grilos (quiyu, em guarani) encontramos menção aos indígenas que padre Labrador denomina de "inteligentes", os quais atuavam como curandeiros:

En el Paraguay un inteligente los preparaba, como ya digo. Cocía levemente unos Grillos, les sacaba las tripas, molía lo demás; y estos polvos daba en licor conveniente alos que padecían dela orina: fluía esta, y quedaba aliviado el paciente. Otro tostaba dos Grillos en una cazuela de barro, los molia; yen un poco de vino, o de agua bien cocida, o de Chicha (Aloxa) de Maiz los daba a beber al enfermo, que padecia dela retención de la orina; obraba luego el buen efecto. Por el contrario si la enfermedad era de demasiado fluxo de orina, le daba al enfermo un solo Grillo sin tostar, machacado, yen infusión de un poco de agua tíbia. ${ }^{173}$

Em outra ocasião, ele afirma que presenciou dois "inteligentes" e "sábios" indígenas preparando grilos, com o propósito de curar um índio que se encontrava enfermo, e que o procedimento teve resultados positivos. Essa prática de nomeação ou adjetivação de certos indígenas traz consigo um caráter de distinção, na medida em que Labrador, apesar de não percebê-los como iguais aos cientistas europeus, os diferencia também dos demais indígenas. Para François Hartog, a nomeação do outro faz parte do processo da retórica da alteridade e envolve, principalmente, a classificação deste outro, que seria essencial, pois "classificando o outro, classifico-me a mim mesmo e tudo se passa como se a tradução se fizesse sempre na esfera da versão". ${ }^{174}$

Importante lembrar que as observações que Labrador fez do emprego de insetos na cura de certas enfermidades decorrem das experiências que vivenciou como missionário na Província Jesuítica do Paraguai. Esta especial condição - de religioso com a missão de evangelizar e civilizar os indígenas - se manifestará, sem dúvida, nas apreciações que fará das práticas curativas indígenas. Neste sentido, vale ressaltar que:

La separación que realizaba el jesuita entre indígenas 'más racionales' y 'menos racionales' se basaba en el uso de especies vegetales como medicamentos, porque para él la medida de la lógica se daba en relación con el acercamiento al mundo natural, utilizando y aprovechando sus ventajas, a la vez que se despreciaba lo sobrenatural (el shamanismo, la magia en suma), prueba clara de irracionalidad. ${ }^{175}$

No Paraguay Natural, Sánchez Labrador parece estar em sintonia com os avanços no estudo dos invertebrados - particularmente dos insetos - observados no século XVIII, uma vez que não se contenta em referi-los como "bichos venenosos" ou como organismos "imperfeitos" e, por isso, não dignos de atenção. Opondo-se a esta forma tão negativa de perceber os insetos, aponta para as virtudes terapêuticas de alguns deles e para seu largo uso pelos indígenas americanos. Em razão disso, o Livro sobre os "pequeños vivientes" - 
como a eles se referia Sánchez Labrador - não se caracteriza por descrições fantasiosas, crenças arraigadas ou por incorporações de informações não apuradas obtidas com terceiros, oferecendo, ainda, evidências do estreito convívio do jesuíta com os indígenas junto aos quais atuou como missionário.

Sánchez Labrador apresenta suas virtudes e indicações, tencionando sua adequação ao sistema europeu e à teoria humoralista hipocrático-galênica, em consonância com sua condição de europeu e de religioso, não desconsiderando os saberes próprios dos grupos indígenas com os quais conviveu. Neste sentido, é importante ressaltar a posição privilegiada ocupada pelos jesuítas missionários na produção e divulgação do conhecimento científico e etnográfico americano, pois, como bem observado por alguns estudiosos, eles cumpriram "una importante función en la búsqueda de información", pois se encontravam fisicamente na América, "conviviendo con los indígenas y en un medio ambiente lleno de objetos naturales 'novedosos' y por lo tanto esperando su catalogación". ${ }^{176}$

101 Nesta perspectiva, é correto afirmar que os registros que Labrador fez dos saberes e das práticas curativas indígenas - que se caracterizavam pelo emprego de plantas e de insetos - levaram em conta, tanto as obras que consultou na biblioteca do noviciado de San Luis de Sevilha e, posteriormente, na do Colégio de Córdoba, quanto o diálogo que estabeleceu com outros homens de ciência - durante seu exílio em Ravena, na Itália - período durante o qual dedicou-se à sistematização das informações levantadas na América e à escrita do Paraguay Católico e do Paraguay Natural.

Por outro lado, Sánchez Labrador estabeleceu contínuas relações e comparações entre as práticas curativas indígenas e as europeias, fundamentando suas observações, como procuramos demonstrar, no conhecimento divulgado por autoridades em Medicina e Farmácia. Em algumas situações, contudo, ele contestou certas concepções europeias, contrapondo-as às observações e as experiências que realizou durante o período de sua atuação como missionário junto aos indígenas da região platina. Sua narrativa parece, portanto, sobrepor e mesclar as experiências que vivenciou na América àquelas próprias de seu período de formação na Europa e, ainda, às que posteriormente viveu durante o exílio na Itália.

\section{Considerações Finais}

Como procurarmos demonstrar neste artigo, Paraguay Natural Ilustrado constitui-se, inequivocamente, em obra de referência para a reconstituição do ambiente intelectual em que irmãos e padres jesuítas se encontravam inseridos tanto na América, quanto na Europa após o decreto de expulsão dos monarcas ibéricos, para a compreensão dos efeitos da experiência americana nas concepções relativas à Botânica, à Medicina e à Farmácia dos missionários da Companhia de Jesus, e, ainda, para a identificação e avaliação da contribuição dos saberes dos grupos indígenas americanos na escrita de Historias Naturales e Materias Medicas divulgadas no século XVIII.

Esperamos que as passagens que destacamos das Partes Primera, Segunda, Terceira e Quarta da obra e as análises que compartilhamos com os leitores sobre as virtudes medicinais de terras e águas, de algumas plantas nativas americanas, das pedras bezoares e de certos insetos, bem como as reflexões que fizemos sobre a circulação de saberes e o diálogo que o jesuíta Sánchez Labrador manteve com autores clássicos e modernos e com 
outros membros da Companhia de Jesus, instiguem os pesquisadores a conhecerem mais sobre o Paraguay Natural Ilustrado.

Por fim, esperamos, em breve, poder divulgar a transcrição dos demais tomos, livros e capítulos desta obra, que permanece ainda inédita e à espera dos pesquisadores interessados em desvendar suas potencialidades e no amplo leque de temas associados aos campos da História, da Geografia, da Biologia (Botânica e Zoologia), da Arqueologia, Geologia e Paleontologia, da Linguística, da Medicina e da Farmácia que Paraguay Natural Ilustrado apresenta.

\section{Fonte:}

Sánchez Labrador, José. (1771-1776). Paraguay Natural. Ilustrado. Noticias del pais, con la explicación de phenomenos physicos generales y particulares: usos útiles, que de sus producciones pueden hacer varias artes. Ravenna. (Manuscrito). Archivo Histórico de la Compañía de Jesús (ARSI), Roma.

\section{BIBLIOGRAPHY}

Almeida, C. (2010). Medicina mestiça: saberes e práticas curativas nas Minas setecentistas. São Paulo: Annablume.

Anagnostou, S.; Fechner, F. (2011). Historia Natural y Farmácia misionera entre los jesuítas en el Paraguay. Em WILDE, G. (Ed.), Saberes de la conversión. Jesuítas, indígenas e impérios coloniales en las fronteras de la Cristiandad, (pp. 175-190). Buenos Aires: SB.

Asúa, M. de. (2010). La ciencia de Mayo. La cultura científica en el Río de la Plata, 1800-1820. Buenos Aires: Fondo de Cultura Económica.

Asúa, M. de. (2013). El primer trabajo científico en el Río de la Plata. En Sesión Plenaria de la Academia Nacional de Ciencias de Buenos Aires, 27 de mayo de 2013. Disponível em: <http:// www.ciencias.org.ar/user/As\%FAa\%20Primer\%20trabajo\%20cient\%EDfico_MODIFICADO.pdf>. Acesso em: 08 nov. 2016.

Asúa, M. de. (2014). Science in the Vanished Arcadia. Knowledge of Nature in the Jesuit Missions of Paraguay and Río de la Plata, Leiden. Boston: Brill.

Azara, F. de. ([1809] 1998). Viajes por la America Meridional, T. I e II. Buenos Aires: El Elefante Blanco.

Baldini, U. (1992). Legem Impone Subactis: Studi su Filosofia e Scienza dei Gesuiti in Italia, 1540-1632. Roma: Bulzoni Editore.

Barcelos, A. (2013). O Mergulho no Seculum. Porto Alegre: Editora Animal.

Biblioteca Nacional. (1968). Livro de Tombo do Colégio de Jesus do Rio de Janeiro. Rio de Janeiro: Biblioteca Nacional. 
Borschberg, P. (2006). O comércio, uso e falsificação dos bezoares de porco-espinho na Época Moderna. Oriente, (14), 60-78.

Bouza-Álvarez, F. (2001-2002). Cultura escrita e história do livro: a circulação manuscrita nos séculos XVI e XVII. Leituras: Revista da Biblioteca Nacional, Lisboa BN. 9-10, 63-95.

Camenietzki, C. (2005). La Ciencia barroca del padre Kircher. Artes de México, (82), 28-30.

Carolino, L.; Camenietzki, C. (Orgs.). (2005). Jesuítas, ensino e ciência - séc. XVI-XVIII. Casal de Cambra: Caleidoscópio.

Castex, M. et al. (1963a). Acerca de uma nueva especie de raya fluvial: "Potamotrygon Ladradori”. Neotropica, XII.

Castex, M. et al. (1963b). El libro de "Peces" en el manuscrito del P. José Sánchez Labrador "El Paraguay Natural". Anales del Museo Provincial de Ciencias Naturales "Florentino Ameghino". El género “Potamotrygon” en el Paraná Medio, por Mariano N. Castex, Tomo II (1), 62-70.

Castex, M. (1963c). La Raya Fluvial: Notas histórico-geográficas. Santa Fe: Castellvi.

Castex, M. (Ed.). (1968). Sánchez Labrador, J. Peces y aves del Paraguay Natural Ilustrado 1767. Buenos Aires: Compañía General Fabril Editora.

Castillo Gómez, A. (2004). Das tabuinhas ao hipertexto: uma viagem na história da cultura escrita. Lisboa: Biblioteca Nacional.

Certeau, M. de. (1982). A escrita da história. Rio de Janeiro: Forense Universitária.

Certeau, M. de. (2011). A escrita da história ( $3^{\circ}$ ed.). Rio de Janeiro: Forense Universitária.

Del Valle, I. (2009). Escribiendo desde los márgenes: colonialismo y jesuítas em el siglo XVIII. México: Siglo XXI.

Di Liscia, M. (2002). Saberes, Terapias y Prácticas Médicas en Argentina (1750-1910). Madrid: Consejo Superior de Investiga Científicas Instituto de Historia.

Domingues, B. (2007). Tão longe, tão perto: a Ibero-América e a Europa Ilustrada. Rio de Janeiro: Museu da República.

Esguerra, J. C. (2007). Como escribir la historia del Nuevo Mundo: historiografias, epistemologias e identidades en el mundo del Atlantico del siglo XVIII. México: Fondo de Cultura Económica.

Falkner, T. ([1774] 1836). Descripción de Patagonia y de las partes adyacentes de la América meridional con la religión, política, costumbres y lenguas de sus moradores y algunas particularidades relativas a las islas Malvinas. Em De Angelis, P. de., Colección de obras y documentos relativos a la Historia Antigua y Moderna de las Províncias del Río de la Plata. Tomo II. Buenos Aires: Imprenta del Estado.

Fleck, E. (2014). Entre a caridade e a ciência: a prática missionária e científica da Companhia de Jesus (América platina, séculos XVII e XVIII) (1ed.). São Leopoldo, RS: Oikos Editora.

Fleck, E. (2015). As artes de curar em um manuscrito jesuítico inédito do Setecentos: um estudo do Paraguay Natural Ilustrado do padre José Sánchez Labrador (1771-1776) (1 ed.). São Leopoldo, RS: Oikos Editora.

Furlong, G. (1938). Entre los Pampas de Buenos Aires (Según notícias de los misioneros jesuitas Matías Strobel, José Cardiel, Tomás Falkner, Jerónimo Rejón, Joaquín Caamaño, Manuel Querini, Manuel Gracia, Pedro Lozano y José Sánchez Labrador). Buenos Aires: Talleres Gráficos San Pablo.

Furlong, G. (1948). Naturalistas Argentinos durante la dominacion Hispanica. Buenos Aires: Editorial Huapes. 
Furtado, J. (2005). Barbeiros, cirurgiões e médicos na Minas Colonial. Revista do Arquivo Público Mineiro, XLI, 88-105.

Gargnel, J. (2005). La restitución de la "Historia de la conquista de las províncias del Paraguay, Río de la Plata y Tucumán”. Pedro Lozano S.J. (1745) Disponível em: <http://www.unne.edu.ar/ unnevieja/Web/cyt/com2005/2-Humanidades/H-008.pdf>. Acesso em: 08 nov. 2016.

Gargnel, J. (2007). Pedro Lozano S.J., un historiador oficial. Projeto História, São Paulo, 5, 315-323. Gasbarro, N. (2006). Missões: a civilização cristão em ação. Em P. Monteiro (Ed.), Deus na Aldeia: missionários, índios e mediação cultural, (pp. 67-109). São Paulo: Globo.

Giard, L. (2005). La actividad científica en la primera Compañía. Artes de México, (82), 8-19.

Grenón, P. (1922). Piedras Bezares: estudios históricos coloniales. Revista de la Universidad Nacional de Córdoba, Ano 9, Vol. V/VI/VII, 281-302.

Haddad, T. (2014). Filósofos naturais do demônio: astronomia, alteridade e missionação no sul da Índia, século XVII. Revista História Unisinos, XVIII (1), 3-14.

Hartog, F. (1999). O espelho de Heródoto: ensaio sobre a representação do outro. Belo Horizonte: Ed. UFMG.

Huffine, K. (2005). Raising Paraguay from Decline: Memory, Ethnografy and Natural History in the Eighteenth-Century Accounts of the Jesuit Fathers. Em L. Figueroa y D. Ledezma (Eds.), El saber de los jesuitas, historias naturales y el Nuevo Mundo, (pp. 279-302). Madrid: Iberoamericana.

Jolís, J. ([1789] 1972). Ensayo sobre la Historia Natural del Gran Chaco. Resistência: Instituto de Historia de la Universidad Nacional del Nordeste.

Kantor, I. (2010). Resenha de Bleichmer, D. (Ed.). (2009). Science in the Spanish and Portuguese Empires: 1500-1800. Stanford: Stanford University Press. História da Historiografia, (4), pp. 295-296.

Lozano, P. ([1745] 1873). Historia de la Conquista de las Províncias del Paraguay, Río de la Plata y Tucumán. Em Lozano, P., Historia de la Conquista del Paraguay, Río de la Plata y Tucumán, I a V. Buenos Aires: Imprenta Popular.

Millones Figueroa, L. (2005). La intelligentsia jesuíta y la naturaleza del Nuevo Mundo en el siglo XVII. En L. Millones Figueroa y D. Ledezma (Eds.), El saber de los jesuítas, historias naturales y el Nuevo Mundo, (pp. 27-46). Madrid: Iberoamericana.

Millones Figueroa, L.; Ledezma, D. (Eds.). (2005). El saber de los jesuítas, historias naturales y el Nuevo Mundo. Madrid: Iberoamericana.

Micheau, F. (1985). A idade do ouro da medicina árabe. Em Le Goff, J. (apres.), As doenças têm História, (pp. 57-77). Lisboa: Terramar.

Molinari, J. (1938). Sánchez Labrador y su contribución a la materia médica rioplatense. Revista Médica Latinoamericana, (277).

Montenegro, P. (1945). Materia Medica Misionera. Buenos Aires: Edición de la Biblioteca Nacional de Buenos Aires.

Montoya, A. (1985). Conquista espiritual feita pelos religiosos da Companhia de Jesus nas Províncias do Paraguai, Paraná, Uruguai e Tape. Porto Alegre: Martins Livreiro Ed.

Moreno, A. (1948). La Medicina en "el Paraguay Natural” (1771-1776) del P. Jose Sánchez Labrador S. J. Exposición comentada del texto original. Tucuman: Universidad Nacional de Tucuman. 
Motta, E. da. (2014). Viajes por el cuerpo Femenino: Mulheres indígenas, suas práticas e rituais, segundo a obra 'Viajes por la America meridional' de Félix de Azara. Trabalho de Conclusão de Curso (Graduação em História) - Universidade do Vale do Rio dos Sinos.

Moya, S. (2012). El libro manuscrito en la Córdoba del siglo XVIII. El caso de la Physica Particularis de Fr. Elías del Carmen Pereyra. Bibliographica americana, (8), 39-43.

Pacheco, M. (2005). Los jesuítas novohispanos y la naturaleza em el siglo XVIII. En L. Millones Figueroa y D. Ledezma (Eds.), El saber de los jesuítas, historias naturales y el Nuevo Mundo, (pp. 195-197). Madrid: Iberoamericana.

Pickel, D. (2008). Flora do Nordeste do Brasil segundo Piso e Marcgrave: no século XVII (A. Vasconcelos de Almeida, Ed.). Recife: EDUFRPE.

Pratt, M. (1999). Os olhos do Império: relatos de viagem e transculturação. Bauru, São Paulo: EDUSC.

Raj, K. (2007). Relocating modern science. Circulation and the construction of knowledge in South Asia and Europe, 1650-1900. Hampshire: Palgrave Macmillan.

Reis, I. (2009). Um mapa da medicina antiga: Entre a cura através dos contrários e a cura através dos semelhantes. Revista de historia de la medicina y epistemología médica, I, 1-14.

Romano, A. (2005). Las primeras enseñanzas científicas en Nueva España: México entre Alcalá, Mesina y Roma. Takwá, (8), 93-118.

Rosso, C. (2011). Epidemias de viruela en las reducciones chaqueñas de abipones y mocovíes durante siglo XVIII. Eä, II (3), 1-28.

Sainz Ollero, H.; Sainz Ollero, H.; Cardona, F.; Ontañón, M. (1989). José Sánchez Labrador y los naturalistas jesuitas del Río de la Plata. Madrid: Mopu.

Santamaría, D. (2003). Archivo de plantas medicinales de zonas aborígenes y campesinas de Sudamerica. Jujuy: Centro de Estudios Indígenas y Coloniales.

Schwartz, S.; Lockhadt, J. (2002). A América Latina na época colonial. Rio de Janeiro: Civilização Brasileira.

Storni, H. (1980). Catálogo de los Jesuítas de la Província del Paraguay (Cuenca del Plata). Roma: Institutum Historicum Societatis Iesu.

Viale, A. (2015). Comentário bibliográfico - texto de Miguel de Asúa. Science in the Vanished Arcadia. Knowledge of Nature in the Jesuit Missions of Paraguay and Río de la Plata. Rey Desnudo. Revista de Libros, Año IV (7), 49-55.

Zupanov, I. (2005). Missionary Tropics. The catholic frontier in India (16th-17th centuries). History, Languages and Cultures of the Spanish and Portuguese World Series. Ann Arbor, MI: University of Michigan Press.

\section{NOTES}

1. Kantor, 2010, pp. 295-296. A historiadora mexicana Maria Cristina Torales Pacheco, ao refletir sobre o papel desempenhado pela Companhia de Jesus para o impulso das ciências naturais também destacou este aspecto, ressaltando a peculiar sensibilidade barroca que caracterizou a produção jesuítica sobre a natureza americana (Pacheco, 2005, pp. 195-197).

2. Carolino, 2009, pp. 258-259.

3. Domingues, 2007, p. 233. 
4. Millones Figueroa; Ledezma, 2005, p. 22.

5. Millones Figueroa; Ledezma, 2005, p. 9.

6. Baldini, 1992, pp. 9-11.

7. Asúa, 2010, p. 472.

8. Asúa, 2010, p. 472.

9. Asúa, 2010, pp. 192-193.

10. Asúa, 2013, p. 3

11. Ver mais em Asúa, 2014.

12. Del Valle, 2009, p. 240.

13. Millones Figueroa, 2005, pp. 27-28.

14. Esguerra, 2007.

15. Giard, 2005, p. 10.

16. Romano, 2005, pp. 93-118.

17. A imagem da "efervescência" é ricamente explorada por Ines Zupanov (2005); já a ideia da "zona de contato", introduzida por Mary Louise Pratt (1999), foi mobilizada no contexto da história das ciências por Kapil Raj (2007).

18. Para Nicola Gasbarro, a ortopraxis é elemento essencial da missionação jesuítica. Ver mais em Gasbarro, 2006, pp. 67-109.

19. Haddad, 2014, pp. 3-14

20. Haddad, 2014, pp. 6-7.

21. Zupanov, 2005.

22. Haddad, 2014, p. 13.

23. Millones Figueroa; Ledezma, 2005, pp.14-15.

24. Millones Figueroa; Ledezma, 2005, p. 22.

25. Huffine, 2005, pp. 279-302.

26. Ver mais em Viale, 2015.

27. Anagnostou; Fechner, 2011, p. 175.

28. Anagnostou; Fechner, 2011, p. 190. Na Matéria Medica Misionera, de autoria do irmão jesuíta Pedro Montenegro (1710), constata-se o importante papel desempenhado por informantes e copistas indígenas, tanto na identificação, coleta e experimentalismos com plantas nativas, quanto na difusão e circulação dos conhecimentos médicos sistematizados pelos missionários da Companhia de Jesus.

29. Sainz Ollero et al., 1989, pp. 101-102.

30. Huffine, 2005, pp. 295-297.

31. Trata-se do manuscrito Paraguay Natural. Ilustrado. Noticias del pais, con la explicación de phenomenos physicos generales y particulares: usos útiles, que de sus producciones pueden hacer varias artes. Ravenna. (Manuscrito). Archivo Histórico de la Compañía de Jesús (ARSI), Roma, 1771-1776.

32. Millones Figueroa; Ledezma, 2005, p. 10.

33. Mas, se a incorporação das línguas, das práticas terapêuticas, dos saberes e das cosmovisões indígenas pelos jesuítas conferiu, como afirmado por Asúa (2010), uma das "características distintivas da ciência nas missões no Paraguai" (p. 193), nem sempre houve - como bem observado por Di Liscia (2002) - "interesse em reconhecer de onde provinham tais saberes" (p. 299) fundamentais, por exemplo, no manejo da flora e da fauna com fins medicinais.

34. José Sánchez Labrador nasceu em 19 de setembro de 1717, como atestam todos os documentos, com exceção "del catálogo jesuítico de 1742, que da esa misma fecha, pero três años antes". Os autores acrescentam que "En el Archivo de los Tribunales de Córdoba (Argentina) se guarda la Renuncia de sus bienes, fechada en 6 de abril de 1738, en la que puede verse que sus padres se llamaban Juan Sánchez Labrador Y María Hernández, cristianos viejos, y que tenía varrios hermanos" (Saiz Ollero et. al., 1989, p. 101). 
35. Héctor e Helios Sainz Ollero, Francisco Cardona e Miguel de Castro Ontañón recorreram aos Catálogos de 1735, 1739, 1744 e 1748 e à obra de Hugo Storni para afirmar que seu ingresso na Companhia se deu em 19 de setembro de 1732, quando José contava, portanto, com 15 ou 18 anos. 36. "En los años siguientes no conocemos las actividades del recién ordenado sacerdote, aunque por las referencias de sus libros debió de estar, al menos en Buenos Aires y Montevideo" (Sainz Ollero et al., 1989, p. 102).

37. Dentre as inúmeras ocupações que José Sánchez Labrador exerceu antes de atuar como missionário estão as de professor de Gramática no Colégio Máximo de Córdoba, professor de Filosofia na Universidade de Córdoba e professor de Teologia no Colégio Máximo de Buenos Aires. Sobre seu interesse em História Natural, seus trabalhos "demuestran su aprendizaje como naturalista y el interés que le produjo desde um primer momento la naturaleza americana, pero la mayor parte de sus experiências y hallazgos iba a realizarlos en las áreas misioneras" (Sainz Ollero et al., 1989, p. 102).

38. Recomenda-se ver mais em Asúa, 2014. Para o filósofo e historiador argentino, dentre os aspectos que devem ser considerados em uma análise de obras de ciência produzidas por jesuítas no exílio, estão "su background historiográfico, con una tradición bien establecida y propiamente jesuita para escribir sobre la naturaleza del nuevo mundo; la noción de puesta teatral implicada en estos trabajos, subrayando que la visión jesuita de una tierra como la puesta en escena del drama de la salvación en el contexto de un paraíso natural puede ser concebida como una expresión discursiva del theatrum naturae, la concepción del mundo natural como una exhibición a ser contemplada (...)" (Viale, 2015, pp 51-52.).

39. Sánchez Labrador faz referência também às reduções de Yapeyu, Trinidad, Jesús, Loreto, San Ignacio Mini, San Ignacio Guazu, San Cosme y San Damián e San Lorenzo, mas não informa se as conheceu pessoalmente.

40. Sobre esta última viagem realizada pelo jesuíta em território americano, Furlong (1948) e Sainz Ollero et al. (1989) afirmam que Sánchez Labrador teria sido o primeiro a fazer o caminho que ligava as reduções de Guaranis às de Chiquitos [iniciada em dezembro de 1766 e concluída em agosto de 1767], da qual teria resultado um diário e um mapa, entregues a Francisco Bucareli y Ursúa, governador de Buenos Aires à época da expulsão da Companhia de Jesus.

41. Os jesuítas foram expulsos das áreas coloniais do Império em 1767 e suas propriedades foram confiscadas, em cumprimento ao Decreto de 27 de fevereiro, assinado por Carlos III. A expulsão da Companhia de Jesus fazia parte de um conjunto de reformas da Coroa espanhola, conhecido como Reformas Bourbônicas, que tinha como objetivo aumentar o controle do poder real sobre os domínios ultramarinos. Antes de Carlos III, outro déspota esclarecido, D. José I, de Portugal, havia expulsado os jesuítas dos domínios portugueses, em 1759, também buscando subordinar o clero ao Estado. Os jesuítas, além de terem sido acusados de tentar construir um Estado dentro do Estado e de criar intrigas contra o governo espanhol, eram pouco populares entre as demais ordens religiosas, sendo bastante vulneráveis em função de sua independência e de serem os menos enraizados na sociedade hispano-americana. Ver mais em Stuart Schwartz e James Lockhadt, 2002.

42. José Sánchez Labrador e os outros cerca de dois mil jesuítas expulsos da América espanhola foram exilados e se estabeleceram em outras localidades da Europa. Os padres do Vice-reinado do Rio da Prata teriam sido os últimos a deixarem as reduções pelas dificuldades de se encontrarem substitutos, sendo retirados de suas residências entre junho e agosto de 1768. Os documentos encontrados com os jesuítas foram confiscados para que pudessem ser encontradas evidências sobre suas atividades, razão pela qual foram autorizados a viajar somente com suas roupas e breviários. Foram levados, em precárias condições, para Córsega, de onde foram enviados, em sua maioria, para as cidades de Faenza, Ravena, Brisighella e Ímola. Em uma carta datada de 21 de agosto de 1768, de Puntales (Cádiz), encontra-se uma lista de 150 jesuítas que partiram de Buenos Aires, em uma fragata, de nome Esmeralda, que os levaria de volta para a Europa, sob 
responsabilidade do comandante Matheo Collado Neto. Sánchez Labrador estava citado entre os missionários que provinham da Província do Paraguai. Ver mais em Sainz Ollero et al., 1989.

43. Para alguns jesuítas, como o padre José Sánchez Labrador, “la 'expulsión' tuvo paradójicamente uma repercusión positiva sobre su formación científica (...) esta generación de jesuitas que, obligados a abandonar su labor misionera, se dedicaron a ordenar sus datos y a comunicar sus hallazgos y conocimientos a la luz de los avances científicos de la época. (...) reelaboró su obra en Rávenna a la luz de la bibliografía que tuvo ocasión de consultar en esta ciudad italiana" (Sainz Ollero et al., 1989, p. 194). Consideramos que esta riqueza de referencias, provocada por su contacto con la ciencia europea del momento y los autores clásicos, constituye un aspecto fundamental de su obra, que destaca por su erudición y enciclopedismo. “(...) Conocía la obra química de Robert Boyle, había leído a autores clásicos como Hipócrates, Aristóteles, Plínio, Galeno y Dioscórides, alguns árabes como Avicena y contaba con las principales obras médicas de los siglos XVI y XVII, como las de Aldrovandi, Mattioli, Vesalio, Ramazzini, Pisón (...)" (Sainz Ollero et al., 1989, p. 204).

44. Como bem observado por Sainz Ollero et al., "La fecha de edición de este conjunto se sitúa aproximadamente entre 1771-76, cuando estaba exilado en Italia. (...) lo detallado de sus descripciones, unido a ciertas citas que se encuentran en el texto referents a interrupciones en el escribir derivadas de los problemas surgidos en la convivencia diaria con los indios, indican que el padre Sánchez Labrador debió de salvar parte de sus manuscritos originales, lo cual le permitió reconstruir posteriormente descripciones e historias tan detalladas y políficas" (Sainz Ollero et al., 1989, pp. 211-212).

45. A transcrição, análise e divulgação deste manuscrito ainda inédito constituem objetivos da investigação "As artes de curar em dois manuscritos jesuíticos inéditos do Setecentos", que conta com o apoio do CNPq e da CAPES, através do Edital MCTI-MEC-CNPq-CAPES № 22-2014. Como resultado deste projeto de pesquisa, em 2015, foi lançada a obra "As artes de curar em um manuscrito jesuítico inédito do Setecentos: o Paraguay Natural Ilustrado do Padre José Sánchez Labrador (1771-1776), que apresenta a transcrição integral dos Livros da Parte Segunda, o Libro I da Parte Tercera e o Libro III da Parte Quarta.

46. Barcelos, 2013, pp. 92-93. De acordo com Sainz Ollero et al., "sabemos que parte de los documentos de Sánchez Labrador quedaron en América (...) Quizá no conoceremos nunca cuántos escritos pudo llevar consigo Sánchez Labrador al exilio (...)”. Os autores, contudo, sustentam que "es la práctica certeza de que (...) pudo, a pesar de las órdenes de Bucareli, trasldar con él parte de sus escritos hasta su destierro italiano. No podemos dar una explicación cierta de las circunstancias que pudieron provocar esta permisividad extraña. Por lo que sabemos las condiciones de arresto en Asunción fueron mucho más benignas que en el resto de las ciudades del Río de la Plata" (Sainz Ollero et al., 1989, p. 106). Para sustentar esta possibilidade, os autores recorrem a um trecho da Relação escrita pelo próprio Sánchez Labrador ao chegar ao Porto de Santa Maria, na qual o missionário jesuíta informa que havia feito "um viaje em descubrimiento de las Misiones de los Chiquitos (...) en nombre del Rey nuestro Señor y el excelentísimo señor Don Francisco Bucareli y Ursúa Theniente general y Governador de Buenos Ayres le pidió diário exsacto y mapa lo qual todo trabajó y entrego a sua Exª . Quien ofreció remitirlo a su Magd. (...)", apontando para "una relación algo especial entre nuestro autor [Sánchez Labrador] y Bucareli, que pudo significar una cierta permisividad a la hora de sacar algunos papeles no especialmente conflictivos (...)" (Sainz Ollero et al., 1989, p. 107).

47. Considerando a extensão do manuscrito, cujos 4 tomos abarcam um total de 1852 páginas, optamos por anexar ao presente artigo os Sumários e os textos das Introduções das quatro Partes que compõem o manuscrito Paraguay Natural Ilustrado. Recomenda-se ver mais em Fleck, 2015.

48. Esclarecemos que neste artigo, nos detemos, exclusivamente, no Libro I - Animales Quadrupedos , da Parte Tercera, uma vez que os Libros II e III porque já mereceram uma edição parcial feita pelo 
médico argentino Mariano Rafael Castex. Dentre seus trabalhos, destacamos: Castex (1968), Castex (1963a), Castex (1963b), Castex (1963c).

49. De acordo com Sainz Ollero et al. (1989), "se trata de dibujos a pluma de alta calidad em los que se resaltan, en ocasiones exageradamente, los caracteres morfológicos de mayor importância taxonómica. (...) Tanto por su volumen como por la calidad de los mencionados dibujos esta contribución iconográfica se interpreta como de alto valor" (p. 193). Os autores acrescentam que se são indiscutivelmente "uma aportación muy importante, sobre todo considerando que la gran mayoría de estas plantas no han contado com descripciones válidas (linneanas) hasta um siglo después (...)" e as lâminas nos ajudam na sua identificação na atualidade (Sainz Ollero et al., 1989, p. 182).

50. Estes aspectos foram abordados por Fleck (2015).

51. Cabe observar que no Paraguay Natural, o padre jesuíta Sánchez Labrador faz largo uso das notas de rodapé, não se furtando, também, de rasurar e corrigir palavras, frases ou parágrafos inteiros, tema que será explorado em tópico específico deste artigo.

52. Moya, 2012, p. 39.

53. Moya, 2012, pp. 39-43.

54. Trata-se das obras de António Castillo Gómez (2004) e de Fernando Bouza-Álvarez (2001-2002).

55. De Certeau, 2011, p. 244 (grifo do autor).

56. Segundo Sainz Ollero et al. (1989), o paradeiro da obra Paraguay Cultivado é desconhecido desde 1878, ano em que o manuscrito foi leiloado pela Casa Maisonneuve.

57. As únicas informações que se possui sobre o manuscrito foram as que Sainz Ollero e seus colaboradores (1989) puderam encontrar no catálogo do leilão no qual a obra foi vendida. A obra descrita, por ocasião do leilão, era, segundo estes pesquisadores, composta por quatro partes, a saber: Parte 1: 5 libros De la labranza de las tierras; Parte 2: 4 libros De las huertas de Arboles; Parte 3:1 libro De las hortalizas y legumbres e Parte 4: 2 libros Jardines y un apêndice curioso de varios términos con varias instrucciones.

58. Sánchez Labrador, 1772, Tomo II, Introdução, F. Num. I.

59. Sabe-se que o Paraguay Católico foi escrito entre os anos de 1769 e 1770, mas, infelizmente, não podemos precisar o período em que o Paraguay Cultivado foi redigido, uma vez que não temos acesso ao manuscrito. A análise que fizemos do Paraguay Natural Ilustrado nos leva a crer que suas Partes tenham sido as últimas a ser escritas, isto porque, ao longo delas, Sánchez Labrador cita, com frequência, as outras duas obras - Paraguay Católico e Paraguay Cultivado -, destacando, muitas vezes, em qual Parte, Livro ou Capítulo o leitor poderia encontrar certas informações. No primeiro livro do Tomo de Botânica, ele escreve: "Si tales mutaciones se han de admitir por verdaderas, o rechazarse como falsas, conta del que decimos en el Paraguay Cultivado libr. III. Capitulo V" (Sánchez Labrador, 1772, p. 92, grifo nosso). Outra evidência se encontra no livro I do primeiro Tomo, no qual ele indica a leitura do Paraguay Católico, o que, aliás, faz com certa frequência: "Lo demas perteneciente a los establecimientos de los Castellanos en el Paraguay, se podra leer en el Paraguay Catholico" (Sánchez Labrador, 1771, p. 15, grifo nosso).

60. Trata-se do Arquivo Romano da Sociedade de Jesus (ARSI), que se encontra em Roma, Itália.

61. Sánchez Labrador, 1772, Tomo II, Livro VII, p. 472.

62. Dentre as plantas que outro jesuíta que se dedicou à sistematização de informações relativas à Botânica médica da Bacia platina, destaca-se o irmão jesuíta Pedro Montenegro, autor da Materia Medica Misionera (1710), que indica o "taropé", popularmente conhecida como figueirilha, pertencente à espécie Dorstenia brasiliensis Lam., para acidentes com animais peçonhentos, planta que, em trabalhos atuais, é também referida por suas propriedades antiofídicas, diaforéticas e antifebris. Já o padre jesuíta José Sánchez Labrador se detém nas virtudes medicinais de animais tidos como peçonhentos, tais como aranhas e escorpiões, que abundavam em certas regiões da Província Jesuítica do Paraguai, destacando sua utilidade no tratamento de certas enfermidades. 
63. Sánchez Labrador, 1771, Tomo I, Introdução, p. Num. I.

64. Sánchez Labrador, 1771, Tomo I, Introdução, p. Num. I.

65. Sánchez Labrador, 1771, Tomo I, Introdução, p. Num. I.

66. Sánchez Labrador, 1771, Tomo I, Livro I, Cap. VI, p. 45.

67. O médico e físico Robert James (1703-1773/1776) nasceu em Staffordshire e faleceu em Londres. Ficou conhecido por ter desenvolvido o chamado "pó de febre", uma importante invenção para a medicina do século XVIII. Sánchez Labrador recorre bastante às suas obras “ Farmacopea Universal" e "Dicionário Médico" (1743) (Moreno, 1948, p. 21).

68. O químico francês Nicolas Lemery nasceu em Ruan, em 1645, e morreu em Paris, no ano de 1715. Era membro da Academia de Ciências e sua obra mais famosa foi Curso de Química (1675). Sánchez Labrador, no entanto, refere outras obras suas, tais como Farmacopea Universal (1697), Tratado Universal das drogas simples (1698), Tratado do Antimônio (1707) e Nova Recopilação de segredos e curiosidades mais raros (1709) (Moreno, 1948, p. 21).

69. Sánchez Labrador, 1771, Tomo I, Livro I, Cap. VII, p. 51.

70. Sánchez Labrador, 1771, Tomo I, Livro I, Cap. VII p. 56.

71. Sánchez Labrador, 1771, Tomo I, Livro I, Cap. VII, p. 56.

72. Sánchez Labrador, 1771, Tomo I, Livro I, Cap. III, p. 19.

73. Para saber mais sobre as práticas abortivas e de infanticídio das indígenas na Província Jesuítica do Paraguai registradas por Félix de Azara em sua obra Viajes por la America Meridional (1809), recomenda-se ver a monografia de conclusão do Curso de Graduação em História de Elisa Fauth da Motta (2014).

74. Azara, [1809], 1998, p. 63.

75. Azara, [1809], 1998, pp. 62-63.

76. Montenegro, [1710], 1945, p. 336.

77. Sánchez Labrador, 1771, Tomo I, Livro II, Cap. II, p. 314.

78. Sánchez Labrador, 1771, Tomo I, Livro II, Cap. IV, p. 328.

79. Sánchez Labrador, 1771, Tomo I, Livro II, Cap. II, p. 308.

80. Ver mais em Freitas Reis, 2009.

81. Micheau, 1985, p. 46.

82. Sánchez Labrador, 1771, Tomo I, Livro III, Cap. IX, p. 532.

83. Sánchez Labrador, 1771, Tomo I, Livro III, Cap. IX, p. 533.

84. Sánchez Labrador, 1771, Tomo I, Livro III, Cap. IX, p. 533.

85. Sánchez Labrador, 1771, Tomo I, Livro III, Cap. IX, p. 534.

86. Sánchez Labrador, 1771, Tomo I, Livro III, Cap. IX, p. 535.

87. Sánchez Labrador, 1771, Tomo I, Livro III, Cap. IX, p. 536.

88. Sánchez Labrador, 1771, Tomo I, Livro III, Cap. IX, p. 536.

89. Jacobo Boncio (?-?) atuou como médico da Companhia Holandesa em Java.

90. O médico e naturalista holandês Guilhermo Piso (1611-1678) atuou em uma expedição ao Brasil, entre os anos de 1637 e 1644, tendo atuado como médico particular do conde Maurício de Nassau (1604-1679), governador da colônia holandesa instalada no Nordeste do Brasil, no período de 1636 a 1644. Escreveu, juntamente com George Marcgraf, a obra "Historia Naturalis Brasilieae" (1648), primeira publicação científica sobre a geografia e natureza do Brasil (Pickel, 2008).

91. Sánchez Labrador, 1771, Tomo I, Livro III, Cap. IX, p. 537.

92. De acordo com Sainz Ollero et al. (1989), as primeiras cem páginas do Tomo de Botânica consistem em uma Introdução de caráter geral sobre Botânica, na qual Sánchez Labrador revela não apenas conhecer os trabalhos do botânico sueco Carlos Lineu, mas também posicionar-se em relação à metodologia e à classificação lineanas, considerando imprecisos os procedimentos nomenclaturais por ele sugeridos (Sainz Ollero et al., 1989, pp. 177-209).

93. Para Daniel Jorge Santamaría (2003), organizador da obra Archivo de Plantas Medicinales de Zonas Aborígenes y Campesinas de Sudamerica, resultante de projeto desenvolvido por pesquisadores 
do Centro de Estudos Indígenas y Coloniales e do Centro Regional de Investigación, Capacitación y Desarrollo, de Jujuy, Argentina, é preciso considerar - diante da variedade das plantas e de seus usos pelos diferentes grupos nativos americanos - os limites e as dificuldades para a "reconstrucción histórica de los medicamentos empleados", devido a fatores como "la oscura identificación de muchas plantas en una época en que cronistas, misioneros y viajeros todavia no utilizaban la sistemática de Linneo; muchos informes etnográficos modernos mencionan con frecuencia plantas sin designación científica; frecuentemente se indican solo los nombres de las plantas utilizadas sin anotar su preparación y posologia y el inviolable silencio que guardan los médicos aborígenes en torno das plantas empleadas en aliviar los males" (Santamaría, 2003, pp. 9-10).

94. Para Sainz Ollero et al. (1989) e Furlong (1948), Paraguay Natural foi iniciado na América, mas concluído em Ravena, durante o exílio na Itália. De acordo com Ruiz Moreno (1948), as referências que Sánchez Labrador faz ao Diccionario razonado universal de historia natural del señor Bomare, que começou a ser publicado em 1765, parecem ser um indicativo de que a obra foi concluída, de fato, na Itália, pois, segundo ele, dificilmente o jesuíta teria consultado o Diccionario do naturalista e farmacêutico francês quando ainda se encontrava na América, não somente pelas dificuldades de sua circulação a partir de Assunção, após uma eventual aquisição pelo Procurador da Companhia de Jesus, e pelo isolamento da missão de Belén, onde ele missionava, mas também porque, de início de dezembro de 1766 a início de agosto de 1767, Sánchez Labrador se encontrava em viagem às Missões de Chiquitos, para, em seguida, ser enviado à Europa, juntamente com outros companheiros da Ordem.

95. Sánchez Labrador, 1772, Tomo II, Livro VI, Cap. X, p. 408.

96. De acordo com essa teoria, o corpo humano seria formado por diferentes líquidos ou humores que eram quase sempre quatro (Sangue, Fleuma, Bílis Amarela e Bílis Negra). A saúde consistiria no equilíbrio desses humores, assim como a enfermidade consistiria no predomínio de algum deles sobre os demais. Ver mais em Ivoni Freitas Reis, 2009.

97. Carolus Linnaeus, em português Carlos Lineu (1707-1778), foi um botânico, zoólogo e médico sueco, criador da nomenclatura binomial e da classificação científica, sendo assim considerado o "pai da taxonomia moderna". Foi um dos fundadores da Academia Real das Ciências da Suécia.

98. O agrupamento por formas biológicas foi proposto por Joseph Pitton de Tournefort (1656-1708), um botânico francês nascido em Aix-en-Provence e falecido em Paris, que ficou conhecido por ter sido o primeiro autor a tratar mais especificamente do conceito de gênero para as plantas, influenciando uma série de outros naturalistas e botânicos que se basearam em seu trabalho para criar seus próprios sistemas de classificação. Sua principal obra foi "Eléments de botanique, ou Méthode pour reconnaître les Plantes", publicada em 1694. "La filosofía botánica de Tournefort (1656-1708) era la que impregnaba los trabajos que se ocupaban de las plantas durante la primera mitad del siglo" (Sainz Ollero et al., 1989, p. 175).

99. De acordo com Sainz Ollero, Sánchez Labrador "adoptó una postura prudente, manejando un gran aparato erudito, pero sin defender con claridad ninguna opinión." Pode-se, no entanto, constatar uma parcial aplicação do sistema sexual de Lineu por Sánchez Labrador na "agrupación de las palmeras, muy importantes en la flora local y a las que se dedica una gran atención, con las cañas, gramíneas adaptadas a los ambientes priódicameente encharcados, pertenecientes ambas al gran grupo e las monocotiledóneas" (Sainz Ollero et al., 1989, pp. 179-213).

100. A regra da nomenclatura binomial das espécies ficará cristalizada na obra Species Plantarum, publicada em 1753, na qual foram relacionadas 5.900 espécies - distribuídas em 1098 gêneros designadas por duas palavras. Vale lembrar que somente a partir do século XVII, as plantas passaram a ser descritas a partir de critérios de classificação, tais como morfologia vegetal, taxonomia, fisiologia vegetal, anatomia e sistemática, e não mais, exclusivamente, a partir de suas propriedades medicinais. 
101. Sainz Ollero et al. informam que, em pleno período de Renascimento científico, na Espanha, diferentemente da Itália e de outros países europeus, existia "una cierta 'Linneofobia' (...) encabezada por el catalán José Quer, director del recién creado Jardín Botânico de Madrid, a causa de ciertos comentários despectivos que el naturalista sueco había realizado sobre los botânicos españoles" (Sainz Ollero et al., 1989, p. 175).

102. Sánchez Labrador, 1772, Tomo II, Introdução, f. num. I (grifos nossos).

103. Sánchez Labrador, 1772, Tomo II, Introdução, f. num. I (grifos nossos).

104. Sánchez Labrador, 1772, Tomo II, Livro III, Cap. I, p. 139.

105. No caso de outras espécies de madeiras existentes na vasta região da Província Jesuítica do Paraguai, Labrador também se detém em informações sobre sua utilização na construção - como pontes, casas e igrejas -, e na confecção de instrumentos musicais, ferramentas e de imagens sacras. Dentre as 48 plantas que teriam utilidade em construções, Labrador destaca a Urundey ( Astronium spp.), da espécie da família das Fabáceaes, popularmente conhecida como Pau-ferro e nativa das regiões de savanas da América do Sul. Por possuir um lenho bastante resistente, esta madeira era largamente utilizada nas reduções jesuíticas tanto nas construções, quanto na confecção de imagens sacras e obras torneadas, merecendo a seguinte descrição: “Arbol alto, y durissimo, parece un hierro. Su madera sirve para Horcones, Trapiches, y cosas, que hande estar debaxo de tierra, ò del agua. De ella salen muy ballas las obras de Torno y semejantes" (Sánchez Labrador, 1772, Tomo II, Libro II, Cap. IV, p. 122).

106. Sánchez Labrador, 1772, Tomo II, Livro II, Cap. IV, p. 124.

107. Sánchez Labrador, 1772, Tomo II, Livro II, Cap. IV, p. 123.

108. Sánchez Labrador, 1772, Tomo II, Livro II, Cap. IV, p. 123.

109. Sánchez Labrador, 1772, Tomo II, Livro VI, p. 448 (grifos nossos)

110. Sánchez Labrador, 1772, Tomo II, Livro VI, pp. 365-366 (grifos nossos).

111. Sánchez Labrador, 1772, Tomo II, Livro VI, p. 434 (grifos nossos).

112. Sánchez Labrador, 1772, Tomo II, Livro VI, p. 369 (grifos nossos).

113. Sánchez Labrador, aliás, manifesta sua estranheza diante da constatação de que nenhum dos estudiosos por ele referidos menciona os bezoares dos guanacos e das antas, aventando a possibilidade de que estes autores tenham achado suficiente citar apenas os cervos como representantes de todos estes. 0 jesuíta chega a comparar estes estudiosos com os antigos gregos e latinos, que também não referiram as pedras bezoares orientais e nem os animais que as produziam, não descuidando de observar que a ausência de informações sobre elas não indicava que não existissem nesse período.

114. Almeida, 2010, p. 113.

115. Coube aos árabes e aos modernos a identificação das virtudes medicinais do bezoar oriental e do bezoar ocidental, o que explicaria o grande número de palavras árabes a elas referidas, como Hager Alzbesahar, Piedra Alexipharmaca, Balzaha e bedezahar, que podiam ser encontradas no Tratado de Gaspar Bauhin (1560-1624). Tidos como mercadoria rara e muito preciosa tanto no mercado europeu, quanto no asiático, os bezoares foram colocados em uma categoria de "produtos suntuários e mágicos", dentre os quais se encontravam as "pedras preciosas e pérolas" e os "chifres de unicórnio". Labrador irá criticar esta percepção difundida por alguns autores da Antiguidade, para quem a utilização da pedra bezoar estaria vinculada à "credulidad, superticion, y impostura humana" (Sánchez Labrador, 1772, Tomo III, Livro I, Cap. VII, p. 59).

116. Grenón, 1922, p. 284.

117. Sánchez Labrador, 1772, Tomo III, Livro I, p. 56.

118. Em sua obra Conquista espiritual, de 1639, o padre Antônio Ruiz de Montoya fornece informações sobre as práticas curativas adotadas pelos indígenas da Província Jesuítica do Paraguai: "Usam os índios muitos remédios e ervas medicinais que lá a natureza tem produzido. A pedra de São Paulo é de ajuda comprovada; são-no também os alhos esmagados, ingerido o remédio como bebida; a pedra bezoar e outras ervas medicinais" (Montoya, 1985, p. 25). 
119. Sánchez Labrador, 1772, Tomo III, Livro I, Cap. V, p. 50 (grifos nossos).

120. O padre jesuíta José Cardiel nasceu em La Guardia, em 1704. Desembarcou em Buenos Aires, em 1729 e, dois anos depois, foi designado para as reduções de indígenas Guarani. De 1729 a 1767, atuou como missionário entre os abipones, mocobis, charruas, pampas e serranos, vindo a falecer no exílio, em Faenza, na Itália, em dezembro de 1782.

121. Cardiel, 1938, p. 28.

122. Ver mais em José Jolís, [1789], 1972. Sobre padre Jolís, sabe-se que nasceu na Espanha, em 1728, e que foi missionário na região oeste do Chaco. Foi durante o exílio, em Faenza, que ele dedicou-se a escrever, a partir das memórias das viagens que realizou pela região, a obra Ensayo sobre la Historia Natural del Gran Chaco, finalizada em 1789, um ano de sua morte.

123. $O$ autor de A description of Patagonia and adjoins parts of South America, publicada em Hereford, em 1774, nasceu em Manchester, Inglaterra, no ano de 1702. Na condição de médico, iniciou viagem para a América, em 1730. Chegou ao Rio da Prata a bordo de um navio negreiro e, adoentado, foi socorrido pelo padre Sebastián de San Martin, o que o levou a se converter ao catolicismo e a ingressar na Companhia de Jesus em 1732. Atuou como médico e boticário no Colégio de Córdoba, onde se encontrava quando do decreto de expulsão de Carlos III. Não se conhecem as circunstâncias de seu regresso à Inglaterra, mas foi lá que faleceu em janeiro de 1784.

124. Falkner, [1774], 1836, pp. 30-31 (grifos nossos).

125. Alonso de Ovalle foi um destacado cronista e missionário jesuíta, natural de Santiago do Chile. Como Procurador da Vice-Província Jesuítica do Chile, percorreu cidades da Espanha e da Itália em busca de missionários. Sua obra Historica Relacion del Reyno de Chile foi publicada originalmente em Roma, em 1646.

126. Sánchez Labrador, Tomo III, Livro I, Cap. V, p. 49.

127. Pedro Lozano nasceu em Madri, em 1697, e ingressou na Companhia de Jesus em 1711. Chegou à América em 1714 e no ano seguinte passou a atuar como professor de Filosofia e Teologia em Córdoba, função que exerceu até 1724. A partir de 1730 , aparece no catálogo da Ordem como "historiographus provinciae", ocupação que exerceu até sua morte, em Humahuaca, no ano de 1752.

128. De acordo com Josefina Cargnel, "Esta obra es la introducción que Lozano agrega a la Historia de la Compañía de Jesús en el Paraguay encargada por sus superiores; en 1745, por razones no expuestas en las consultas de la Orden, los superiores jesuitas separaron este escrito consagrado a los "sucesos profanos" remitiendo el resto a Europa para que fuera editado. Probablemente las razones económicas primaron para no publicar una obra tan extensa; recordemos los costos de edición de una obra de más de mil páginas, que no había sido encargada por la Orden y por lo tanto no habría respondido a los objetivos que se perseguían con la misma" (2005, p.1). Ver mais em Josefina Gargnel, 2007.

129. Lozano, [1745], 1873, pp. 282-283 (grifos nossos).

130. Os primeiros jesuítas que chegaram ao Chile em 1593 estiveram sujeitos à jurisdição da Província Jesuítica do Peru até 1607, quando foi criada a Província Jesuítica do Paraguai, que passou a controlar a atuação dos missionários na região. Esta situação manteve-se até 1624, ano em que foi criada a Vice-Província Jesuítica do Chile, subordinada novamente à Província do Peru. Somente em 1683 foi criada a Província Jesuítica do Chile.

131. Sánchez Labrador, 1771, Tomo III, Livro I, Cap. V, p. 49.

132. Sobre as pedras bezoares formadas nos estômagos dos porcos-espinhos, recomenda-se ver mais em Peter Borschberg, 2006.

133. Sánchez Labrador, 1771, Tomo III, Livro I, Cap. V, p. 48. Ao longo do Terceiro Tomo de sua obra, Labrador traz informações sobre a formação da pedra bezoar, ressaltando que, quase sempre, em seu centro havia algum corpo estranho - corpo heterogêneo - que era formado por uma substância muito diferente da que compunha a pedra. Esse corpo heterogêneo poderia ser, por 
exemplo, uma semente de fruto, ao redor do qual se formaram as capas ou folhas bezoárdicas, que se constituiriam da seguinte maneira: o fruto ou planta, ingerido pelo animal, causaria a condensação dos licores que se encontravam no estômago, os quais, por sua natureza adstringente, favoreceriam a formação de uma matéria pegajosa e nitrosa, que se encaminharia para o piloro, onde se prenderia ao fruto ou à pedra que ali se encontrava, formando, assim, a primeira capa do bezoar, que daria origem ao restante da pedra.

134. O químico e médico Esteban Francisco Geoffroy (1672-1731) nasceu e faleceu em Paris. Foi ainda professor de química do Jardim Botânico de Paris (1707), professor de Medicina e Farmácia no Colégio de França (1709) e decano da faculdade de Medicina de Paris (1726). Tem sua obra "Matéria Médica" citada com frequência por Sanchez Labrador (Moreno, 1948, p. 22).

135. O naturalista alemão George Marcgraf (1610-1644) tinha formação em matemática, história natural, astronomia e medicina. Realizou expedições ao Nordeste brasileiro (1637-1644), tendo contado com o patrocínio de Maurício de Nassau (1604-1679), governador da colônia holandesa no Nordeste do Brasil, de 1636 até 1644. Inicialmente, foi escalado para ser auxiliar de Piso, mas, depois, assumiu funções de geógrafo, cartógrafo, astrônomo e meteorologista. Escreveu, juntamente com Guilhermo Piso, o livro "Historia Naturalis Brasilieae", publicado em 1648 (Pickel, 2008).

136. Sánchez Labrador, 1771, Tomo III, Livro I, Cap. VII, p. 57 (grifos nossos). A menção feita ao irmão jesuíta, que, muito provavelmente, atuava como boticário junto ao Colégio da Ordem, em Salamanca, evidencia a rede de circulação de saberes e de medicamentos entre a América e a Europa que a Companhia manteve ao longo dos séculos XVII e XVIII.

137. Sánchez Labrador, 1771, Tomo III, Livro I, Cap. VII, p. 56.

138. Sánchez Labrador, 1771, Tomo II, Livro III, Cap. V, p. 170.

139. Sánchez Labrador, 1771, Tomo III, Livro I, Cap. VII, p. 54.

140. Sánchez Labrador, 1771, Tomo III, Livro I, Cap. VII, p. 56.

141. A historiadora argentina Cintia Natalia Rosso (2011), em artigo que aborda as epidemias de varíola nas reduções chaquenhas de indígenas abipones e mocobis, informa que "En Europa los remédios más comúnmente utilizados para la viruela eran las sangrías, la aplicación del calor, la provocación de sudor y la llamada 'cura roja"' (p. 12). Ainda de acordo com Rosso, o padre jesuíta Martin Dobrizhoffer, em sua obra História de Los Abipones, de 1784, teria mencionado a indicação do uso de pedras bezoares no tratamento da varíola pelo médico alemão Johann Jacob Woyts [em obra de 1727], o que parece se justificar, já que eram empregadas como "modelo terapêutico netamente extractivo de los 'malos humores' corporales” (Rosso, 2011, p. 13).

142. Sánchez Labrador, 1771, Tomo III, Introdução, F. XXXIV.

143. Ver mais em Di Liscia, 2002, pp. 1-51.

144. Montenegro, 1945, p. 142.

145. Ver mais em Fleck, 2014, pp. 330-340.

146. Em estudo sobre as boticas da capitania de Minas Gerais setecentista, a historiadora Junia Ferreira Furtado também constatou que eram utilizados: “(...) entre outros bezoárticos, o âmbar gris, que se formava no intestino de cachalotes; a pedra de porco-espinho, considerada o mais eficaz dos bezoares do Oriente e indicada nos casos de vômitos, fraqueza de estômago, aflições do coração, afetos uterinos das mulheres, 'paixões dos rins', retenção de urina e febres malignas. No Brasil, essa preciosidade era fornecida pelos porcos-do-mato'. As pedras encontradas na cabeça do jacaré eram utilizadas no combate à febre; a pedra lipes servia 'para consumir as carnes supérfluas das chagas e para curar as da boca'; a pedra-ume suspendia as diarréias após a evacuação dos humores" (Furtado, 2005, p. 103).

147. Já os olhos de caranguejo, referidos nos inventários da botica do colégio de Córdoba, figuram entre os medicamentos empregados "nos problemas estomacais, de rins e bexiga" (Furtado, 2005, p. 104). Também o inventário do colégio do Rio de Janeiro, realizado no ano de 1759 , revela que as pedras bezoares ou Bezuarticas podiam ser encontradas nas prateleiras de sua botica, aparecendo 
entre os remédios que, na opinião do inventariante, deveriam ser colocados à venda "por serem couzas corrutiveiz" (Biblioteca Nacional, 1968, p. 135).

148. Sánchez Labrador, 1776, Tomo IV, Livro III, Cap. Último, p. 361.

149. Sánchez Labrador, 1776, Tomo IV, Livro III, Cap. Último, p. 361.

150. O jesuíta alemão Athanasius Kircher (1601-1680) foi professor de Matemática, Física e Alquimia, no Colégio Romano, onde se dedicava também à pesquisa. Constituiu uma ampla rede de informação, contando com a colaboração de missionários da Ordem que, do Oriente e do Ocidente, remetiam os relatos de suas observações astronômicas ou estudos que haviam realizado sobre a fauna e a flora nativas. Carlos Ziller Camenietzki, ao tratar dos estudos de ciências naturais desenvolvidos pelo jesuíta A. Kircher, afirmou que "Utilizar la idea barroca de la agudeza para explicar su manera de abordar el mundo natural nos ayuda a entender la naturaleza de sus explicaciones. (...) las ideas de Kircher y la heterodoxia de sus bases metafísicas sugiere la existencia de conexiones importantes entre el pensamiento científico y las manifestaciones culturales en en siglo XVII. Era una época barroca" (Camenietzki, 2005, pp. 29-30).

151. A utilização destes insetos como um contraveneno, isto é, como um antídoto contra seu próprio veneno, constitui-se em evidência da aceitação e aplicação da medicina dos contrários por Sánchez Labrador.

152. Sánchez Labrador, 1776, Tomo IV, Livro III, Cap. Último, p. 366 (grifos nossos).

153. $O$ destaque dado por Sánchez Labrador às suas virtudes medicinais e à indicação de insetos tratamentos de pedras nos rins e na bexiga nos levou a investigar as possíveis causas da alta incidência destas enfermidades entre os grupos indígenas da região platina. Constatamos que dietas ricas em proteína, sódio (sal) ou açúcar podem levar à formação de cálculos reais, que são formações endurecidas nos rins ou nas vias urinárias, resultantes do acúmulo de cristais existentes na urina. No caso das dietas com presença elevada de sal, elas aumentam a quantidade de cálcio que os rins deverão filtrar, o que, consequentemente, leva a um risco maior. Também, o baixo consumo de líquidos ou doenças do trato digestivo, como inflamação gastrointestinal e diarréia crônica podem causar mudanças no processo de digestão, afetando diretamente na absorção de cálcio e água, aumentando também as chances de formação de pedras nos rins e/ou bexiga. Outra causa para a formação de cálculos renais é o excesso ou, então, a falta de citrato, substância presente, principalmente, nas frutas cítricas, a hipo e hipercitraturia.

154. Jacques-Christophe Valmont de Bomare (1731-1807) foi um farmacêutico e naturalista francês, nasceu em Rouen e morreu em Chantilly. Começou a publicar suas obras em 1764, com o "Dicionário fundamentado universal de história natural" citado com frequência por Sánchez Labrador. Também escreveu a obra "Mineralogia ou Nova exposição do reino mineral" (Moreno, 1948).

155. O epigrafista latino Marco Valério Marciel (38/40 d.c. - ?) nasceu e morreu em Bílbilis, na Espanha, tendo como sua principal obra Liber spectaculorum (80 d.C.).

156. $O$ escritor e médico greco-romano Pedânio Dioscórides (40 d.C.-90 d.c.) escreveu a obra De Materia Medica, considerado o manual de farmacopeia mais importante da Grécia e Roma antigas. 157. O inglês Martin Lister (1638-1712) foi naturalista, médico e físico. Ficou conhecido como o criador do balonismo de aranhas, como o "pai" da concologia - estudo científico das conchas de moluscos - e como o criador do histograma. Suas principais obras são: Historiae animalium Angliae tres tractatus (1678), Historiae Conchyliorum (1685-1692) e Conchyliorum Bivalvium (1696).

158. O médico e farmacêutico alemão Johann Schröder (1600-1664) é tido como o primeiro a reconhecer o arsênio como um elemento em 1649, ano em que produziu a forma do arsênio e publicou dois métodos de preparação do elemento. Suas obras principais são: Pharmacopoeia medico-chymica sive thesaurus pharmacologicus (...) (1644) e Vollständige und nutz-reiche Apotheke/ $\operatorname{Oder}(. .).(1709)$. 
159. O médico, filósofo e cirurgião romano Cláudio Galeno (129-199/217 d.C.) nasceu em Pérgamo, na região da Mísia, na Ásia Menor, e foi uma das figuras mais destacadas da medicina romana. É conhecido por ter defendido que a saúde do homem dependia do equilíbrio dos quatro humores, assim como havia afirmado Hipócrates (460-377 a. C.).

160. Sánchez Labrador, 1776, Tomo IV, Livro III, Cap. Último, p. 368.

161. Sánchez Labrador, 1776, Tomo IV, Livro III, Cap. Último, p. 362.

162. Sánchez Labrador, 1776, Tomo IV, Livro III, Cap. Último, p. 362.

163. Sánchez Labrador, 1776, Tomo IV, Livro III, Cap. Último, p. 369.

164. Sánchez Labrador, 1776, Tomo IV, Livro III, Cap. Último, p. 363.

165. Sánchez Labrador, 1776, Tomo IV, Livro III, Cap. Último, p. 363.

166. Sánchez Labrador, 1776, Tomo IV, Livro III, Cap. Último, p. 363

167. Sánchez Labrador, 1776, Tomo IV, Livro III, Cap. Último, p. 365.

168. Sánchez Labrador, 1776, Tomo IV, Livro III, Cap. Último, p. 366.

169. Sánchez Labrador, 1776, Tomo IV, Livro III, Cap. Último, p. 366.

170. Sánchez Labrador, 1776, Tomo IV, Livro III, Cap. Último, p. 368.

171. Sánchez Labrador, 1776, Tomo IV, Livro III, Cap. Último, p. 368.

172. Certeau, 1982, p. 82.

173. Sánchez Labrador, 1776, Tomo IV, Livro III, Cap. Último, p. 366.

174. Hartog, 1999, p. 259.

175. Di Liscia, 2002, p. 40.

176. Del Valle, 2009, p. 52.

\section{ABSTRACTS}

In this article, we present and analyze the manuscript Paraguay Natural Ilustrado, written by the Jesuit Father José Sánchez Labrador, between the years 1771-1776, while he was exiled in Ravena, Italy. This work, that is located at the Archivo Romanum Societatis Iesu (ARSI), is divided in four tomes - Ground, Water and Air; Botany; Mammals, Birds and Fishes; Amphibians, Reptiles and Insects - in which, besides of the perceptions about American nature, we found information related with the knowledge and healing practices adopted by the indigenous populations from the vast region of the Jesuit Province of Paraguay. Beyond of the therapeutic virtues of waters, grounds, plants, bezoar stones and insects described in this work, our interest is, too, demonstrate that in the Paraguay Natural Ilustrado the missionary Sánchez Labrador has reunited information derived from both his own observations and the ones that he obtained with the indigenous; as information found in works produced by other Jesuits or lay scientists, with whom he established an interesting dialog. The production and circulation evidences of the knowledge and practices, in special, related with Medicine and Pharmacy, and, too, with the appropriation of the knowledge of intelligent and wise indigenous will be, therefore, approached too.

Neste artigo, apresentamos e analisamos o manuscrito Paraguay Natural Ilustrado, escrito pelo padre jesuíta José Sánchez Labrador, entre os anos de 1771-1776, durante seu exílio em Ravena, na Itália. Esta obra, que se encontra no Archivo Romanum Societatis Iesu (ARSI), se subdivide em quatro tomos - Terra, Água e Ar; Botânica; Mamíferos, Aves e Peixes; Anfíbios, Répteis e Insetos nos quais, além das percepções sobre a natureza americana, encontramos informações relativas 
aos saberes e as práticas curativas adotadas pelas populações indígenas das regiões da vasta Província Jesuítica do Paraguai. Para além das virtudes terapêuticas de águas, terras, plantas, pedras bezoares e insetos descritas na obra, interessa-nos, também, demonstrar que no Paraguay Natural Ilustrado o missionário Sánchez Labrador reuniu informações procedentes tanto de suas próprias observações e das que obteve com os indígenas, quanto das que se encontravam em obras redigidas por outros jesuítas ou por cientistas leigos, com os quais estabeleceu um interessante diálogo. As evidências de produção e circulação de saberes e práticas, em especial, de Medicina e Farmácia, e, também, de apropriação dos conhecimentos dos inteligentes e sábios indígenas serão, por isso, também abordadas.

INDEX

Keywords: Jesus Company, Paraguay Natural Ilustrado, José Sánchez Labrador S. J., circulation of knowledge, Medicine

Palabras claves: Companhia de Jesus, Paraguay Natural Ilustrado, José Sánchez Labrador S.J., circulação de saberes, Medicina

\section{AUTHORS}

\section{ELIANE CRISTINA DECKMANN FLECK}

Universidade do Vale do Rio dos Sinos - Unisinos, Brasil

ecdfleck@terra.com.br

\section{MARIANA ALLIATTI JOAQUIM}

Universidade do Vale do Rio dos Sinos - Unisinos, Brasil mari.alliatti@gmail.com

\section{MAICO BIEHL}

Universidade do Vale do Rio dos Sinos - Unisinos, Brasil

maicobiehl@yahoo.com.br 